\title{
Increased Membrane Cholesterol Might Render Mature Hippocampal Neurons More Susceptible to $\beta$-Amyloid- Induced Calpain Activation and Tau Toxicity
}

\author{
Alexandra M. Nicholson and Adriana Ferreira \\ Department of Cell and Molecular Biology, Feinberg School of Medicine, Northwestern University, Chicago, Illinois 60611
}

\begin{abstract}
A growing body of evidence suggests that $\beta$-amyloid $(\mathrm{A} \beta)$, the main component of senile plaques, induces abnormal posttranslational processing of the microtubule-associated protein tau. We have recently described that, in addition to increasing tau phosphorylation, $\mathrm{A} \beta$ enhanced calpain activity leading to the generation of a toxic $17 \mathrm{kDa}$ tau fragment in cultured hippocampal neurons. How aging, the greatest Alzheimer's disease (AD) risk factor, might regulate this proteolytic event remains unknown. In this study, we assessed the susceptibility of cultured hippocampal neurons to $\mathrm{A} \beta$-dependent $17 \mathrm{kDa}$ tau production at different developmental stages. Our results revealed that mature neurons were more susceptible to $\mathrm{A} \beta$-induced calpain activation leading to the generation of this fragment than young neurons. In addition, the production of this fragment correlated with a decrease in cell viability in mature hippocampal neurons. Second, we determined whether membrane cholesterol, a suspect player in AD, might mediate these age-dependent differences in $\mathrm{A} \beta$-induced calpain activation. Filipin staining and an Amplex Red cholesterol assay showed that mature neuron membrane cholesterol levels were significantly higher than those detected in young ones. Furthermore, decreasing membrane cholesterol in mature neurons reduced their susceptibility to $\mathrm{A} \beta$-dependent calpain activation, $17 \mathrm{kDa}$ tau production, and cell death, whereas increasing membrane cholesterol in young neurons enhanced these $\mathrm{A} \beta$-mediated cellular processes. Finally, fura- 2 calcium imaging indicated that membrane cholesterol alterations might change the vulnerability of cells to $\mathrm{A} \beta$ insult by altering calcium influx. Together these data suggested a potential role of cholesterol in linking aging to $\mathrm{A} \beta$-induced tau proteolysis in the context of $\mathrm{AD}$.
\end{abstract}

\section{Introduction}

Alzheimer's disease (AD) is a common neurodegenerative disorder characterized by the presence of two pathological hallmarks in affected brain areas. These hallmarks include senile plaques of extracellular $\beta$-amyloid (A $\beta)$ deposits, generated by $\beta$ - and $\gamma$-secretase cleavage of the amyloid precursor protein (APP), and intracellular neurofibrillary tangles (NFTs) composed primarily of hyperphosphorylated tau (Glenner and Wong, 1984; Kosik et al., 1986; Wood et al., 1986; Selkoe, 1994; Vassar et al., 1999). While these abnormal protein aggregates coexist in AD brains, how they are linked in AD pathogenesis has not been completely elucidated. Many studies have identified $A \beta$-dependent tau phosphorylation as a cause of toxicity in $\mathrm{AD}$ [for review, see Lee (1996), Imahori et al. (1998), Tsai et al. (2004), Pevalova et al. (2006), and Takashima (2006)]. More recently, research efforts have turned to the potential role of $\mathrm{A} \beta$-induced proteolytic processing of tau in neurite degeneration. Emerging evidence suggests that two proteases, caspase- 3 and calpain, mediate tau cleavage in the presence of $A \beta$. It has been shown that caspase- 3

\footnotetext{
Received Feb. 19, 2009; accepted March 9, 2009.

This study was supported by National Institutes of Health Grant R01 NS39080 and Alzheimer's Association Grant 57869 to A.F.

Correspondence should be addressed to Dr. Adriana Ferreira, Cell and Molecular Biology Department, Northwestern University, Ward Building 8-140, 303 East Chicago Avenue, Chicago, IL 60611. E-mail: a-ferreira@northwestern.edu.

DOI:10.1523/JNEUROSCI.0862-09.2009

Copyright $\odot 2009$ Society for Neuroscience $\quad$ 0270-6474/09/294640-12\$15.00/0
}

cleaved tau at $\mathrm{Asp}^{421}$, enhancing tau aggregation properties in the presence of $\mathrm{A} \beta$ (Chung et al., 2001; Gamblin et al., 2003). Furthermore, a neurotoxic $17 \mathrm{kDa}$ tau fragment as the result of $\mathrm{A} \beta$ induced activation of calpain, a calcium $\left(\mathrm{Ca}^{2+}\right)$-dependent cysteine protease, has been identified in a culture model of AD (Park and Ferreira, 2005). This calpain-mediated tau cleavage preceded phosphorylation, suggesting that the activation of this enzyme leading to the generation of $17 \mathrm{kDa}$ tau might be an early event in $\mathrm{AD}$ pathogenesis (Park and Ferreira, 2005).

How aging, the greatest risk factor for $\mathrm{AD}$, is involved in these $\mathrm{AD}$ pathogenic cascades remains unclear. It has been previously shown that $A \beta$ induced weaker tau phosphorylation in young cultured neurons than in mature ones (Ferreira et al., 1997). However, developmental changes in $\mathrm{A} \beta$-induced tau cleavage have not been studied. These changes could depend on the complement of tau isoform expressed throughout the maturation of hippocampal neurons. Studies performed using neurons that develop either in situ or in culture showed that tau undergoes agedependent alternative splicing of exons 2, 3, and 10 in central neurons. Fetal isoforms lacking all three exons are more abundant in immature neurons. Conversely, isoforms containing these exons are the most abundant in mature neurons (Kosik et al., 1989; Ferreira et al., 1997). Alternatively, aging could modulate the proteolytic processing of tau by regulating the expression levels and/or the activation state of proteases in response to different cellular insults (Kenessey et al., 1990; Benuck et al., 1996; Manya et al., 2002). 
In the present study, we conducted experiments to assess agedependent differences in $\mathrm{A} \beta$-induced calpain-mediated $17 \mathrm{kDa}$ tau production in cultured hippocampal neurons. The data described here indicated that in the presence of $\mathrm{A} \beta$, mature neurons were more susceptible to calpain cleavage of tau into the $17 \mathrm{kDa}$ fragment and cell death than young ones. In addition, this change in the susceptibility of neurons to A $\beta$ toxicity occurred concomitantly with a developmental increase in membrane cholesterol levels. Furthermore, while decreasing mature neuron membrane cholesterol levels to that of young cells reduced their susceptibility to $\mathrm{A} \beta$-induced tau cleavage by calpain, increasing young neuron membrane cholesterol levels to that of mature cells enhanced their vulnerability to $\mathrm{A} \beta$ insult. These changes in susceptibility to $\mathrm{A} \beta$-induced calpain-mediated tau cleavage correlated with significant alterations in $\mathrm{Ca}^{2+}$ influx. Together, these results suggested that $\mathrm{A} \beta$-dependent calpain activation leading to tau cleavage might be developmentally regulated, at least in part, through membrane cholesterol.

\section{Materials and Methods}

Hippocampal culture preparation. Embryonic day 18 Sprague Dawley rat embryos were used to prepare primary hippocampal cultures as previously described (Goslin et al., 1998). Briefly, hippocampi were dissected and freed of meninges. The cells were dissociated by trypsinization $(0.25 \%)$ for $15 \mathrm{~min}$ at $37^{\circ} \mathrm{C}$, followed by trituration with a fire-polished Pasteur pipette. The cell suspension was then plated at high density in minimum essential medium (MEM) with $10 \%$ horse serum (MEM10) on poly-L-lysine-coated dishes (800,000 cells/60 mm dish). After $4 \mathrm{~h}$, the medium was changed to glia-conditioned MEM containing $0.1 \%$ ovalbumin, $0.1 \mathrm{~mm}$ sodium pyruvate, and $\mathrm{N} 2$ supplements ( $\mathrm{N} 2$ medium) (Bottenstein and Sato, 1979). For immunocytochemistry experiments, hippocampal neurons were plated at low density $(150,000$ cells $/ 60 \mathrm{~mm}$ dish) onto poly-L-lysine-coated coverslips in MEM10. After $4 \mathrm{~h}$, the coverslips were transferred to dishes containing an astroglial monolayer and maintained in N2 medium. Neurons were kept in culture for 7, 12, 17, or $21 \mathrm{~d}$.

$A \beta$ aggregation. Synthetic $\mathrm{A} \beta_{1-40}$ and $\mathrm{A} \beta_{1-42}$ (American Peptide) were dissolved to $0.5 \mathrm{mg} / \mathrm{ml}$ in $\mathrm{N} 2$ medium and incubated for $4 \mathrm{~d}$ at $37^{\circ} \mathrm{C}$ to preaggregate the peptides (Ferreira et al., 1997). Neurons were incubated in the presence of the preaggregated peptide at concentrations ranging from 10 to $20 \mu \mathrm{M}$ for $8-24 \mathrm{~h}$ (Park and Ferreira, 2005).

Immunocytochemistry. Hippocampal neurons were cultured on coverslips for 7 to $21 \mathrm{~d}$ before treatment with or without $20 \mu \mathrm{M} \mathrm{A} \beta$. Cells were fixed $24 \mathrm{~h}$ later in $4 \%$ paraformaldehyde (PFA) in PBS containing 0.12 $\mathrm{mm}$ sucrose for $15 \mathrm{~min}$, and permeabilized in $0.3 \%$ Triton X-100 in PBS for $4 \mathrm{~min}$. Coverslips were incubated in $10 \%$ bovine serum albumin in PBS at room temperature for $1 \mathrm{~h}$ before labeling with anti- $\alpha$-tubulin primary antibody (clone DM1A; 1:1000; Sigma) followed by a fluorescein-conjugated secondary antibody (AlexaFluor 488; 1:200; Invitrogen). Images were taken using a Photometrics Cool Snap HQ2 camera coupled to a fluorescent microscope (Nikon Diaphot). Images were analyzed using MetaMorph Image Analysis software (Universal Imaging, Fryer).

Electrophoresis and immunoblotting. Whole-cell lysates were prepared from $7,12,17$, and $21 \mathrm{~d}$ in culture hippocampal neurons that had been incubated with or without $\mathrm{A} \beta$ or cholesterol-altering drugs (see below) by harvesting them in Laemmli buffer. Lysates were homogenized by boiling for $10 \mathrm{~min}$, after which they were loaded and run on SDSpolyacrylamide gels as previously described (Laemmli, 1970). The proteins were transferred onto Immobilon membranes (Millipore Bioscience Research Reagents) and immunoblotted (Towbin et al., 1979; Ferreira et al., 1997). Immunodetection was performed using a phosphorylation-independent anti-tau (clone tau5; 1:1000; BioSource International), anti-spectrin (1:1000; Millipore Bioscience Research Reagents), anti-calpain-1 (1:5000; EMD Biosciences), anti-calpastatin (1: 200; Santa Cruz Biotechnology), and anti- $\alpha$-tubulin (clone DM1A; 1:200,000; Sigma) antibodies. Secondary antibodies conjugated to horse- radish peroxidase (1:1000; Promega) were used followed by enhanced chemiluminescence for the detection of proteins (Yakunin and Hallenbeck, 1998). A ChemiDoc XRS system and Quantity One Software (Bio$\mathrm{Rad}$ ) were used to image and analyze immunoreactive bands. Densitometric values were normalized to $\alpha$-tubulin internal controls.

Cell death assay. Cell viability was assessed by the trypan blue exclusion method as previously described (Black and Berenbaum, 1964; Aras et al., 2008). Briefly, hippocampal neurons cultured on coverslips for $7,12,17$, or $21 \mathrm{~d}$ were incubated in $0.2 \%$ trypan blue stain (Sigma) for $5 \mathrm{~min}$ at room temperature. The cells were rinsed in PBS and immediately counted or fixed for $15 \mathrm{~min}$ in $4 \%$ paraformaldehyde in PBS and stored in PBS at $4^{\circ} \mathrm{C}$. Cells that did not exclude trypan blue were counted as dead cells. Ten nonoverlapping microscopic fields from three independent cultures were analyzed for each experimental condition. Cell death was expressed as a percentage of total cells in each field.

In vitro calpain cleavage of tau isoforms. Six micrograms of recombinant fetal tau, which does not contain exons 2, 3, or 10 (0N3R; EMD Biosciences), or recombinant adult full-length tau, which contains all exons (2N4R; EMD Biosciences), were incubated in the presence or absence of calpain ( $1 \mathrm{U}$; EMD Biosciences) for $1 \mathrm{~h}$ at $37^{\circ} \mathrm{C}$ (Kelly et al., 2005). The digestion reaction was stopped by the addition of an equivalent volume of Laemmli buffer preceding boiling for $10 \mathrm{~min}$. In vitro cleavage product samples were subjected to immunoblotting with a phosphorylation-independent tau antibody (clone tau5; 1:2000; BioSource).

Filipin labeling of membrane cholesterol. Filipin labeling of membrane cholesterol was performed as previously described (Sponne et al., 2004). Hippocampal neurons were cultured for 7 or $21 \mathrm{~d}$ on coverslips, after which they were fixed in 4\% PFA in PBS containing $0.12 \mathrm{~mm}$ sucrose for $15 \mathrm{~min}$ and labeled with $300 \mu \mathrm{g} / \mathrm{ml}$ filipin (Sigma) in PBS for $90 \mathrm{~min}$. After washing with PBS, the cells were fixed for a second time in PFA for 20 min and mounted on a microscope slide. Filipin fluorescence was analyzed $1 \mathrm{~d}$ after staining by taking images at $40 \times$ magnification and $5 \mathrm{~s}$ exposures using MetaMorph Image Analysis software (Universal Imaging) and a Photometrics Cool Snap HQ2 camera coupled to a fluorescent microscope (Nikon Diaphot). Average pixel filipin fluorescence intensity was measured in regions of the soma and processes $(25 \mu \mathrm{m}$ distant from the border of the soma). All values were normalized to the background fluorescence of the corresponding image.

Subcellular fractionation. Seven and twenty-one days in culture hippocampal neurons underwent subcellular fractionation to segregate cytosol and membrane fractions as described previously (van der Bliek et al., 1993; Damke et al., 1994; Kelly and Ferreira, 2007). Briefly, cells were scraped in $5 \mathrm{~mm}$ EDTA in PBS and pelleted by centrifugation for $10 \mathrm{~min}$ at $5000 \mathrm{rpm}$ at $4^{\circ} \mathrm{C}$. Pellets were resuspended in $200 \mu \mathrm{l}$ of fractionation buffer $(0.25 \mathrm{~m}$ sucrose, $1 \mathrm{~mm}$ magnesium chloride, 2 mM EGTA, and 25 mM HEPES, pH 7.4) and lysed by three cycles of flash freezing in liquid nitrogen. Lysates were then centrifuged at $100,000 \times g$ for $30 \mathrm{~min}$ in a Beckman Airfuge (Beckman Coulter). Supernatants (cytosol fraction) were removed and the pellet (membrane fraction) was resuspended in $200 \mu \mathrm{l}$ of fractionation buffer containing 5\% Triton X-100 and briefly sonicated. Whole-cell lysates from the neuronal cultures and rat brain hippocampi were obtained by harvesting or homogenizing the samples in subcellular fractionation buffer containing $2.5 \%$ Triton X-100, followed by brief sonication.

Amplex Red cholesterol quantification. Cholesterol levels were quantified by the Amplex Red cholesterol assay (Invitrogen) in whole-cell, membrane, and cytosol fractions of hippocampal neurons cultured for 7 or $21 \mathrm{~d}$, as well as in whole-cell lysates prepared from the hippocampi of Sprague Dawley rats aged postnatal day 1 (P1)-P180. Briefly, samples were diluted in reaction buffer, after which an equivalent volume of Amplex Red working solution ( $300 \mu \mathrm{M}$ Amplex Red, $2 \mathrm{U} / \mathrm{ml}$ cholesterol oxidase, $2 \mathrm{U} / \mathrm{ml}$ cholesterol esterase, and $2 \mathrm{U} / \mathrm{ml}$ horseradish peroxidase) was added. The samples were incubated at $37^{\circ} \mathrm{C}$ for $30 \mathrm{~min}$ and absorbance was measured at $568 \mathrm{~nm}$ using a Tecan Infinite M200 microplate reader and i-Control software. Cholesterol values were calculated using known cholesterol solutions and normalized to protein content as measured by the modified Lowry technique (Lowry et al., 1951; Bensadoun and Weinstein, 1976). 
Membrane cholesterol modification. Hippocampal neurons cultured for $21 \mathrm{~d}$ were incubated in N2 media containing methyl- $\beta$ cyclodextrin (MBCD; $2 \mathrm{~mm}$; Sigma) for $30 \mathrm{~min}$ to decrease membrane cholesterol levels to that of young neurons (Sponne et al., 2004; Pooler et al., 2006). To increase young neuron membrane cholesterol levels to that of mature neurons, $7 \mathrm{~d}$ in culture hippocampal neurons were treated with $2 \mu \mathrm{g} / \mathrm{ml}$ free cholesterol together with $30 \mu \mathrm{M}$ cholesterol from MBCD complexed with this steroid (MBCD:CH) for $1 \mathrm{~h}$. After either MBCD or MBCD:CH treatment, the media was replaced with drug-free or $\mathrm{A} \beta$ containing $\mathrm{N} 2$ media. The efficiency of MBCD and $\mathrm{MBCD}: \mathrm{CH}$ in altering membrane cholesterol levels was assessed by fractionating the cells and quantifying membrane fraction cholesterol content by means of the Amplex Red cholesterol assay as described above.

Intracellular $\mathrm{Ca}^{2+}$ imaging. Hippocampal neurons cultured for 7 and $21 \mathrm{~d}$ on coverslips were treated with $\mathrm{A} \beta$, cholesterol-modifying drugs, or both. The cells were loaded with $2 \mu \mathrm{M}$ fura-2 $\mathrm{AM}$ (Invitrogen) for $15 \mathrm{~min}$ at $37^{\circ} \mathrm{C}$, washed, and incubated for an additional $15 \mathrm{~min}$ at $37^{\circ} \mathrm{C}$ to allow deesterification of the AM ester (Resende et al., 2007). The cells were mounted in a Series 20 chamber (Warner Instruments) in HEPES buffer ( $5 \mathrm{~mm}$ potassium chloride, 140 mm sodium chloride, 2 mm calcium chloride, 1 mM magnesium chloride, $10 \mathrm{~mm}$ glucose, and 10 mM HEPES, pH 7.4). Using an inverted microscope (Nikon Diaphot) connected to a Photometrics Cool Snap HQ2 camera and MetaMorph/Metafluor Image Analysis software (Universal Imaging), $60 \mathrm{~ms}$ exposures were taken of loaded cells every $10 \mathrm{~s}$ for a total of 15 min to establish baseline $\mathrm{Ca}^{2+}$ concentrations (Sun et al., 2004; Foradori et al., 2007). Fura bound or unbound to $\mathrm{Ca}^{2+}$ was quantified by establishing a ratio between its fluorescence at $510 \mathrm{~nm}$ post excitation at 340 and $380 \mathrm{~nm}$, respectively. Intracellular $\mathrm{Ca}^{2+}$ was quantified by comparing the 340/380 ratio obtained in our cells to that of standard solutions containing fura- 2 and $\mathrm{Ca}^{2+}$ of known concentrations.

Statistical analyses. All experiments performed in this study were conducted three times in at least three independent cultures. The compiled data were analyzed across the experimental conditions using one-way ANOVA followed by Fisher's LSD post hoc test. The values in the graphs represent the mean \pm SEM, and statistical significance is indicated in the graphs for treatments that differed from their respective controls.

\section{Results}

The susceptibility of hippocampal neurons to $\mathrm{A} \boldsymbol{\beta}$-induced tau cleavage increased in an age-dependent manner

It has been previously shown that mature hippocampal neurons cultured in the presence of preaggregated $\mathrm{A} \beta$ are more susceptible to tau hyperphosphorylation than young neurons (Ferreira et al., 1997). However, no comparable information regarding $A \beta$ induced tau cleavage is available. To address this question, we incubated $7,12,17$, and $21 \mathrm{~d}$ in culture hippocampal neurons with $\mathrm{A} \beta$. The cells were fixed $24 \mathrm{~h}$ later and labeled with a tubulin antibody (clone DM1A) to enable morphological observations.
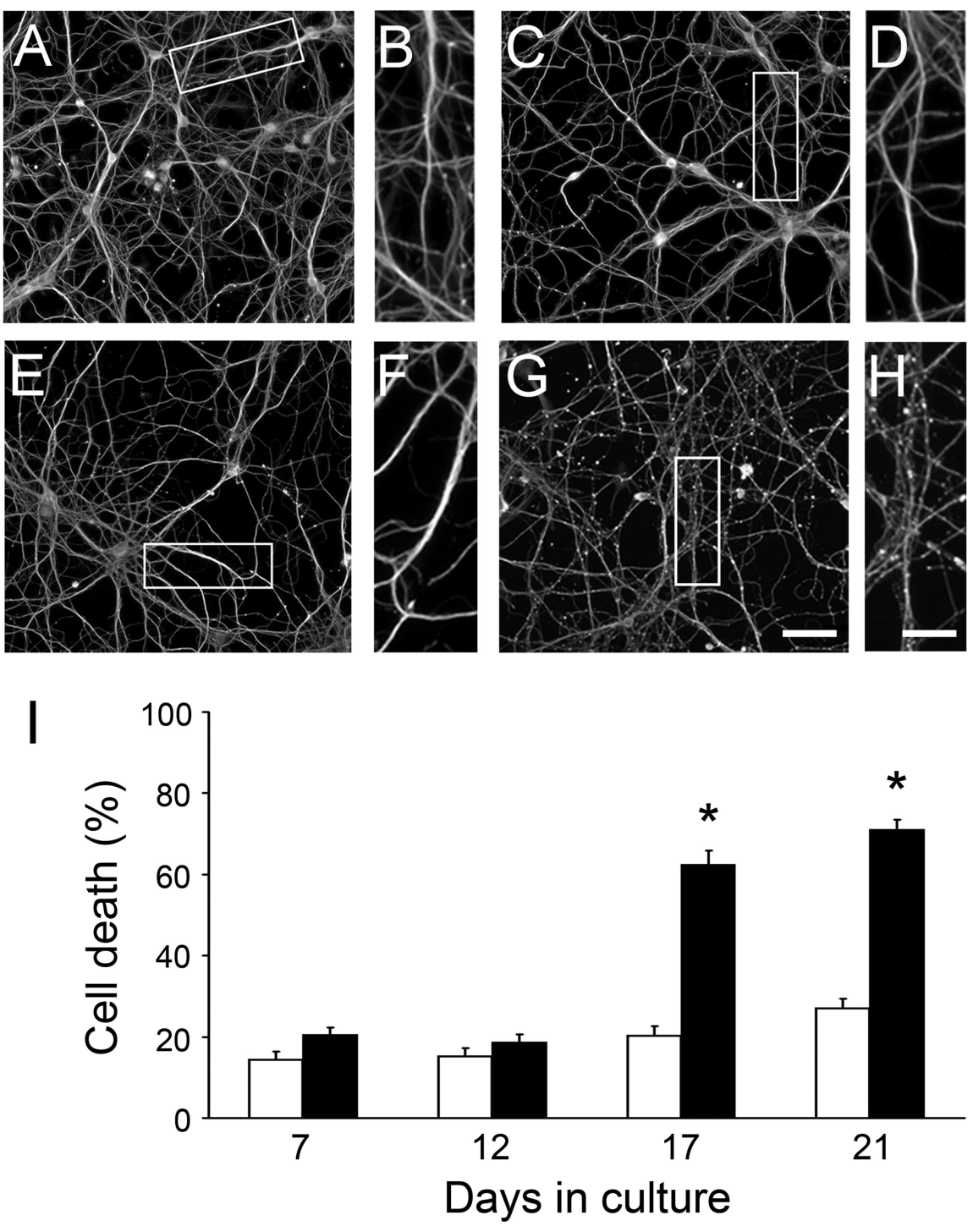

Figure 1. Mature cultured hippocampal neurons were more susceptible to $A \beta$ toxicity than young ones. $\boldsymbol{A}-\boldsymbol{H}$, Seven $(\boldsymbol{A}-\boldsymbol{D})$ and $21(\boldsymbol{E}-\boldsymbol{H})$ days in culture hippocampal neurons that incubated in the absence $(\boldsymbol{A}, \boldsymbol{B}, \boldsymbol{E}, \boldsymbol{F})$ or presence $(\boldsymbol{C}, \boldsymbol{D}, \boldsymbol{G}, \boldsymbol{H})$ of $A \beta$ for $24 \mathrm{~h}$ were labeled using a tubulin antibody. No signs of degeneration were detected in $7 \mathrm{~d}$ in culture neurons treated with $A \beta(\boldsymbol{E}, \boldsymbol{F})$. In contrast, mature neurons displayed morphological signs of degeneration, such as neurite varicosities $(\boldsymbol{G}, \boldsymbol{H})$. Images shown in $\boldsymbol{B}$ treated with (black bars) or without (white bars) $A \beta$ as they aged in culture. $A \beta$-treated mature neurons cultured 17 and $21 \mathrm{~d}$ 列 fields per condition and were expressed as a percentage of total cells. *Differs from untreated controls, $p<0.01$. Scale bars: $A, C$ $\boldsymbol{E}, \boldsymbol{G}, 100 \mu \mathrm{m} ; \boldsymbol{B}, \boldsymbol{D}, \boldsymbol{F}, \boldsymbol{H}, 50 \mu \mathrm{m}$.

By $7 \mathrm{~d}$ in culture, the neurons had developed a complex network of neuritic processes, although this network was more extensive as the cells developed (Fig. $1 A, B, E, F)$. Upon treatment with $\mathrm{A} \beta$, the processes of cells cultured for 7 (Fig. $1 B, C$ ) and 12 (data not shown) d remained intact with no morphological evidence of neurodegeneration. In contrast, 17 (data not shown) and 21 (Fig. $1 G, H)$ d in culture neurons that were incubated in the presence of $\mathrm{A} \beta$ displayed neurites with varicosities as well as neurites undergoing retraction.

To assess whether these $A \beta$-induced developmental changes in neurite morphology correlated with increased cell death, we conducted cell death assays using cultured hippocampal neurons at different ages. Hippocampal neurons cultured for 7, 12, 17, and $21 \mathrm{~d}$ were treated with or without $\mathrm{A} \beta$ for $24 \mathrm{~h}$ and stained with trypan blue. Only viable neurons with an intact plasma 
membrane are able to exclude this large dye from their cytoplasm. Quantification of the percentage of trypan blue-positive (dead) neurons showed no differences when $\mathrm{A} \beta$-treated cultures were compared with their untreated controls 7 and $12 \mathrm{~d}$ after plating (Fig. $1 I)(14.3 \pm 2.1$ and $15.3 \pm 1.9 \%$ vs $20.4 \pm 2$ and $18.5 \pm 2.1 \%$, respectively). Although there was a slight increase in overall cell death as neurons aged in culture, cell death in control and $\mathrm{A} \beta$-treated 7 and $12 \mathrm{~d}$ in culture neurons was similar to that observed in untreated cells cultured for 17 and $21 \mathrm{~d}$ (Fig. 1I) $(20.3 \pm 2.3$ and $27 \pm 2.4 \%$, respectively). On the other hand, the incubation of 17 and $21 \mathrm{~d}$ in culture neurons with $\mathrm{A} \beta$ resulted in a significant increase in cell death compared with their untreated controls (Fig. $1 I)(62.4 \pm 3.4$ and $70.9 \pm 3.6 \%$ respectively).

We next assessed whether the age-related neuronal degeneration and cell death associated with $\mathrm{A} \beta$ treatment in our cells occurred concomitantly with production of the neurotoxic 17 $\mathrm{kDa}$ tau fragment. For these experiments, neurons cultured for 7 , 12,17 , or $21 \mathrm{~d}$ were treated with $\mathrm{A} \beta$ for $24 \mathrm{~h}$, after which the cells were subjected to immunoblotting using a phosphorylationindependent tau antibody (clone tau5). Whole-cell lysates obtained from control and $\mathrm{A} \beta$-treated cells at 7 and $12 \mathrm{~d}$ in culture had an abundance of full-length tau and no detectable tau degradation products at lower molecular weights (Fig. 2 A). Similarly, strong full-length tau immunoreactive bands and a faint tau immunoreactive band at an apparent molecular weight of $17 \mathrm{kDa}$ were detected in 17 and $21 \mathrm{~d}$ in culture controls. In contrast, $\mathrm{A} \beta$ treatment of hippocampal neurons that had been kept in culture for 17 and $21 \mathrm{~d}$ resulted in not only a decrease in the immunoreactivity of full-length tau, but also an increase in tau immunoreactivity at $17 \mathrm{kDa}$ (Fig. $2 \mathrm{~A}$ ). A ratio was then established between the amount of $17 \mathrm{kDa}$ and full-length tau in these lysates (Fig. $2 \mathrm{~B}$ ). Since no $17 \mathrm{kDa}$ tau immunoreactive band was detected in neurons cultured for either 7 or $12 \mathrm{~d}$, we were unable to establish a $17 \mathrm{kDa}$ to full-length tau ratio in these lysates. On the other hand, the $17 \mathrm{kDa}$ to full-length tau ratio was significantly increased in both 17 and $21 \mathrm{~d}$ in culture neurons treated with $\mathrm{A} \beta$ when compared with untreated controls (Fig. $2 B$ ). Similar results were obtained using either $\mathrm{A} \beta_{1-40}$ and $\mathrm{A} \beta_{1-42}$ at concentrations ranging from 10 to $20 \mu \mathrm{M}$ for a duration of $8-24 \mathrm{~h}$ (data not shown; see also Park and Ferreira, 2005).

\section{Age-dependent differences in $\mathrm{A} \beta$-induced $17 \mathrm{kDa}$ tau} production correlated with changes in calpain activation

We next analyzed to what extent developmental differences in tau isoform expression might regulate $\mathrm{A} \beta$-induced calpain cleavage of tau into the $17 \mathrm{kDa}$ fragment. Tau undergoes developmental alternative splicing in rat hippocampal neurons, both in vivo and in culture (Kosik et al., 1989; Ferreira et al., 1997). As a result, the primary tau isoforms expressed in young cultured neurons (fetal isoforms) lack $\mathrm{N}$-terminal exons 2 and 3 as well as exon 10 located in the microtubule binding region of the protein (0N3R) (Ferreira et al., 1997). Contrastingly, mature cultured hippocampal neurons primarily express the adult forms of tau, which contain all three of these exons (2N4R) (Ferreira et al., 1997). For these experiments, both fetal and adult tau recombinant proteins were incubated in the presence of calpain in vitro. The generated tau fragments were subjected to immunoblotting with the clone tau5 antibody. Negative controls, in which calpain was not activated by a $\mathrm{Ca}^{2+}$-containing activation buffer, had few tau degradation products and no apparent band at $17 \mathrm{kDa}$ (Fig. $3 A$ ). On the other hand, the incubation of both fetal and adult tau isoforms with activated calpain resulted in a tau immunoreactive cleavage product of $17 \mathrm{kDa}$ (Fig. $3 A$ ). These results suggested that the
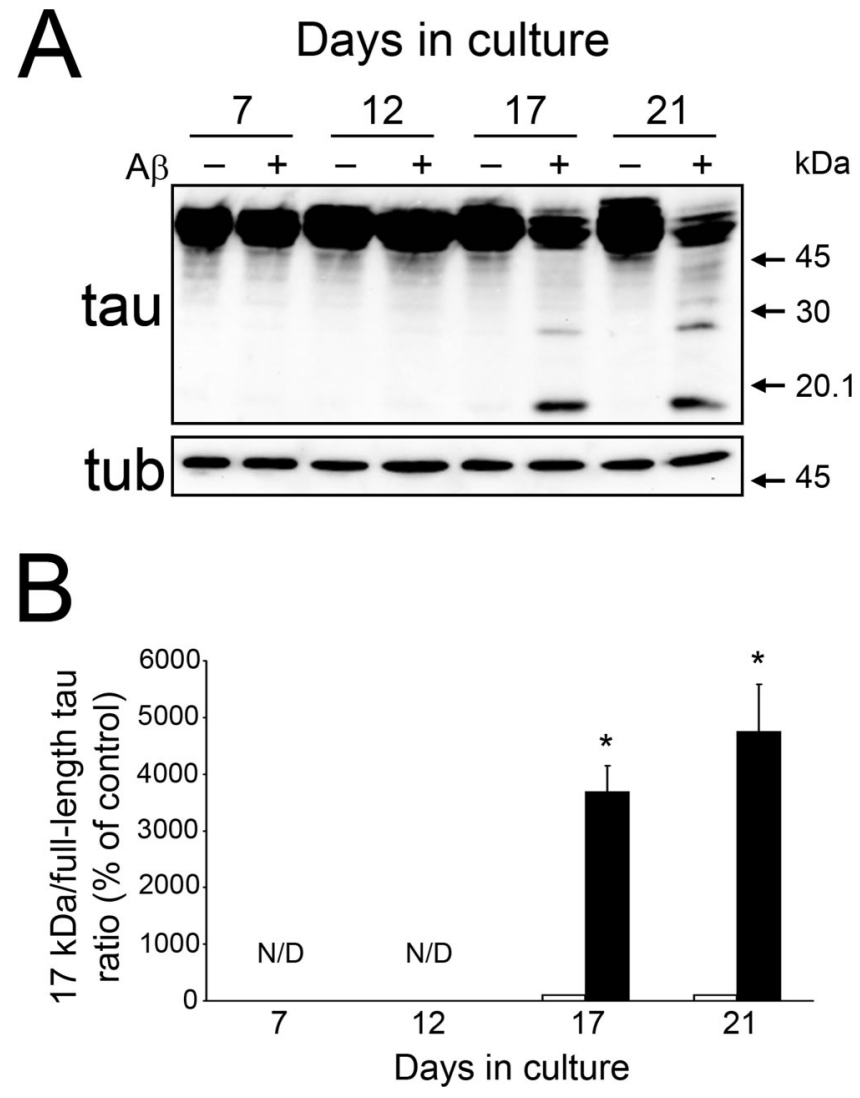

Figure 2. $\quad A \beta$ induced the production of the $17 \mathrm{kDa}$ tau fragment only in mature hippocampal neurons. $\boldsymbol{A}$, Western blot analysis of the $17 \mathrm{kDa}$ tau fragment in whole-cell lysates prepared from $7,12,17$, and $21 \mathrm{~d}$ in culture hippocampal neurons treated with $(+)$ or without $(-) 20$ $\mu \mathrm{M} A \beta$ for $24 \mathrm{~h}$ using a phosphorylation-independent tau antibody (clone tau5). Tubulin was used as a loading control. A strong $17 \mathrm{kDa}$ tau immunoreactive band was detected only in treated hippocampal neurons kept in culture for either 17 or $21 \mathrm{~d}$. $\boldsymbol{B}$, Quantitative analysis of the $17 \mathrm{kDa}$ tau fragment in hippocampal neurons cultured in the absence (white bars) or presence (black bars) of $A \beta$. The $17 \mathrm{kDa}$ densitometry values were calculated as a ratio of full-length tau and represent the mean \pm SEM obtained from at least three independent experiments. The values obtained from untreated neurons were considered $100 \%$. * Differs from untreated controls, $p<0.01$. N/D, Not detectable.

generation of a $17 \mathrm{kDa}$ tau fragment was not dependent on tau isoform expression.

Experiments were then performed to assess whether agerelated differences in $\mathrm{A} \beta$-dependent $17 \mathrm{kDa}$ tau production were a result of changes in calpain activity. To address this question, we first conducted immunoblotting experiments of lysates obtained from young and mature hippocampal neurons cultured in the absence or presence of preaggregated $A \beta$. Blotting membranes were probed with a spectrin antibody to determine the ratio between calpain-cleaved $(150 \mathrm{kDa})$ and full-length $(240 \mathrm{kDa})$ spectrin. Spectrin cleavage from 240 to $150 \mathrm{kDa}$ is an excellent marker for calpain activation that has been shown to produce results comparable to calpain activity assays (Czogalla and Sikorski, 2005; Park and Ferreira, 2005). Untreated neurons at each age displayed a strong spectrin immunoreactive band at $240 \mathrm{kDa}$ with little spectrin cleavage into the $150 \mathrm{kDa}$ fragment (Fig. 3B). Furthermore, full-length spectrin immunoreactivity and quantification of the 150 to $240 \mathrm{kDa}$ spectrin ratio in whole-cell lysates prepared from $\mathrm{A} \beta$-treated neurons cultured for 7 and $12 \mathrm{~d}$ were not significantly different from untreated controls (Fig. 3C). In contrast, there was a significant decrease in immunoreactivity of full-length spectrin that was accompanied by an increase in the 
A

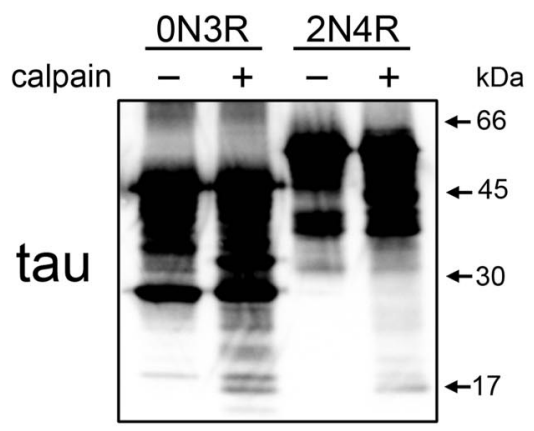

B
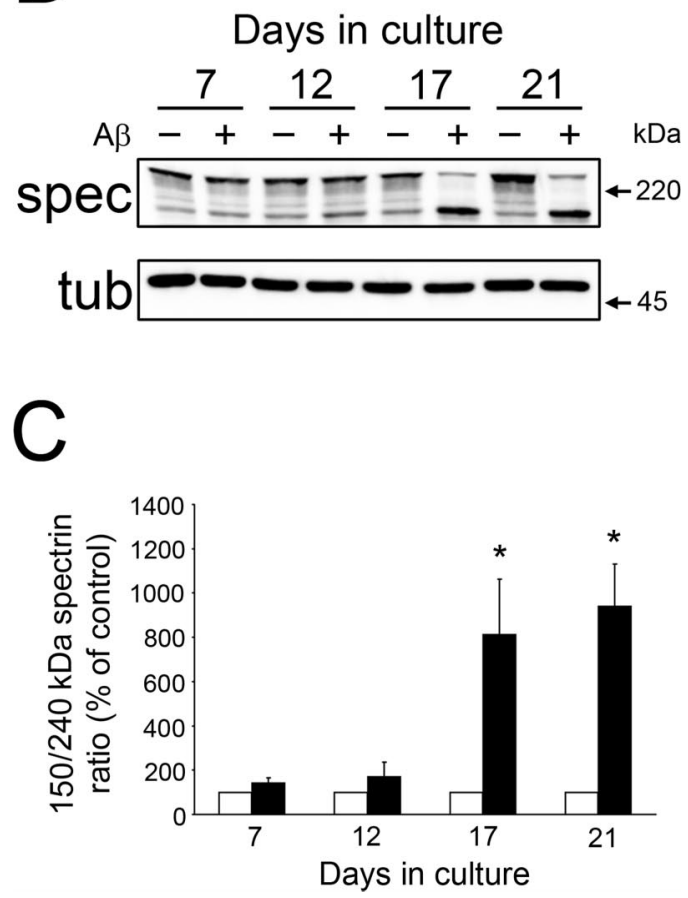

Figure 3. Developmental regulation of $A \beta$-induced $17 \mathrm{kDa}$ generation was dependent on calpain activation and not tau isoform expression. $\boldsymbol{A}$, Six micrograms of recombinant fetal $(0 \mathrm{~N} 3 \mathrm{R})$ and adult (2N4R) tau isoforms were incubated with $(+)$ or without $(-) 1 \mathrm{U}$ of active calpain in vitro. Cleavage products were immunoblotted using a tau antibody (clone tau5). Note the presence of a $17 \mathrm{kDa}$ tau immunoreactive band when either isoform was incubated with calpain. $\boldsymbol{B}$, Western blot of whole-cell lysates obtained from 7, 12, 17, and $21 \mathrm{~d}$ in culture hippocampal neurons cultured in the absence (-) or presence (+) of $20 \mu \mathrm{m} \mathrm{A} \beta$ for $24 \mathrm{~h}$ using a spectrin antibody. Tubulin was used as a loading control. An increase in the $150 \mathrm{kDa}$ immunoreactive spectrin band and a concomitant decrease in full-length spectrin was detected only in mature hippocampal neurons. C, Quantitative analysis of spectrin cleavage by calpain in cultured hippocampal neurons cultured with (black bars) or without (white bars) A $\beta$. A densitometric ratio was established between calpain-cleaved spectrin of $150 \mathrm{kDa}$ and full-length spectrin of $240 \mathrm{kDa}$. The values represent the mean \pm SEM from at least three independent experiments. Untreated controls were considered $100 \%$. ${ }^{*}$ Differs from untreated controls, $p<$ 0.01 .

$150 \mathrm{kDa}$ spectrin immunoreactive band in 17 and $21 \mathrm{~d}$ in culture neurons that were incubated with $\mathrm{A} \beta$ (Fig. $3 B$ ). This change in spectrin band intensities resulted in a significant increase in the 150 to $240 \mathrm{kDa}$ spectrin ratio in $\mathrm{A} \beta$-treated neurons cultured 17 and $21 \mathrm{~d}$ compared with untreated controls (Fig. 3C). These data indicated that age-dependent differences in $17 \mathrm{kDa}$ tau production in response to $\mathrm{A} \beta$ treatment correlated with changes in $\mathrm{A} \beta$ mediated calpain activation in cultured hippocampal neurons.
We next addressed the possibility that this increased $\mathrm{A} \beta$ induced calpain activation in mature neurons compared with young ones was due, at least in part, to developmental changes in the ratio of calpain to its endogenous inhibitor, calpastatin. Immunoblotting of whole-cell lysates from 7 and $21 \mathrm{~d}$ in culture hippocampal neurons with calpain and calpastatin antibodies did not reveal age-related differences in the ratio of these proteins (data not shown). Together, these data suggested that the cellular mechanisms that mediate $\mathrm{A} \beta$-dependent calpain cleavage of tau into the $17 \mathrm{kDa}$ fragment might lie upstream of this enzyme.

\section{Membrane cholesterol levels were developmentally regulated in hippocampal neurons}

Previous research has suggested that components of the plasma membrane might affect calpain activation. This is evidenced by the ability of calpain's third domain to bind lipids, as well as by the ability of phospholipids to reduce the amount of $\mathrm{Ca}^{2+}$ required for calpain activation (Coolican and Hathaway, 1984; Tompa et al., 2001). A component of the plasma membrane known to be involved in mediating the vulnerability of cells to $\mathrm{Ca}^{2+}$ influx is cholesterol (Bastiaanse et al., 1994). Interestingly, membrane cholesterol has been shown to affect $A \beta$ toxicity and also to be developmentally regulated (Igbavboa et al., 1996; Arispe and Doh, 2002; Ehehalt et al., 2003; Subasinghe et al., 2003; Sponne et al., 2004; Igbavboa et al., 2005). Thus, this sterol might be a factor involved in the regulation of age-dependent changes in $\mathrm{A} \beta$-induced calpain activation. To address this question, we first assessed membrane cholesterol levels in young and mature hippocampal neurons using filipin staining. Filipin is a polyene probe which fluoresces upon binding to cholesterol. Both young and mature neurons were fixed and labeled with 300 $\mu \mathrm{g} / \mathrm{ml}$ filipin complex and fluorescence was measured by image analysis using MetaMorph software. Young and mature neurons displayed uniformly distributed filipin labeling in the soma, albeit significantly more concentrated in the $21 \mathrm{~d}$ in culture neurons. Although this probe's fluorescence was visualized in the processes of the young neurons, filipin labeling of mature neuron processes was relatively more intense and extended further into the neurites (Fig. 4A,B). Quantification of the relative filipin fluorescence in both the processes and the soma of the young and mature cells revealed that labeling in each of these areas was greater in the mature neurons by $>150 \%$ (Fig. $4 C$ ). These results suggested that mature hippocampal neurons in culture contained more membrane cholesterol in both the soma and processes than young neurons.

As a more quantitative measure of cholesterol, we performed an Amplex Red cholesterol assay using membrane, cytosol, and whole-cell fractions of young and mature cultured hippocampal neurons. Whole-cell lysates of mature neurons had significantly more cholesterol than young ones $(42.08 \pm 2.84$ vs $26.61 \pm 0.68$ $\mathrm{ng} / \mu \mathrm{g}$ protein, respectively). This difference in whole-cell cholesterol content was accounted for primarily in the membrane fraction of these cells $(85.71 \pm 2.97$ vs $58.76 \pm 2.73 \mathrm{ng} / \mu \mathrm{g}$ protein, respectively), since young and mature neurons did not significantly differ in their cytosolic cholesterol content (Fig. 4D). Finally, we analyzed cholesterol content in brain lysates obtained from rats of different ages to determine whether a developmental increase in cholesterol is a phenomenon that occurs in vivo. For these experiments, lysates were prepared from the hippocampus, the area of the brain primarily affected by $\mathrm{AD}$ pathology, of Sprague Dawley rats aged P1-P180, and analyzed using the Amplex Red cholesterol assay. The hippocampal cholesterol content in these rats increased from $22.8 \pm 5.6 \mathrm{ng} / \mu \mathrm{g}$ protein at $\mathrm{P} 1$ to a 

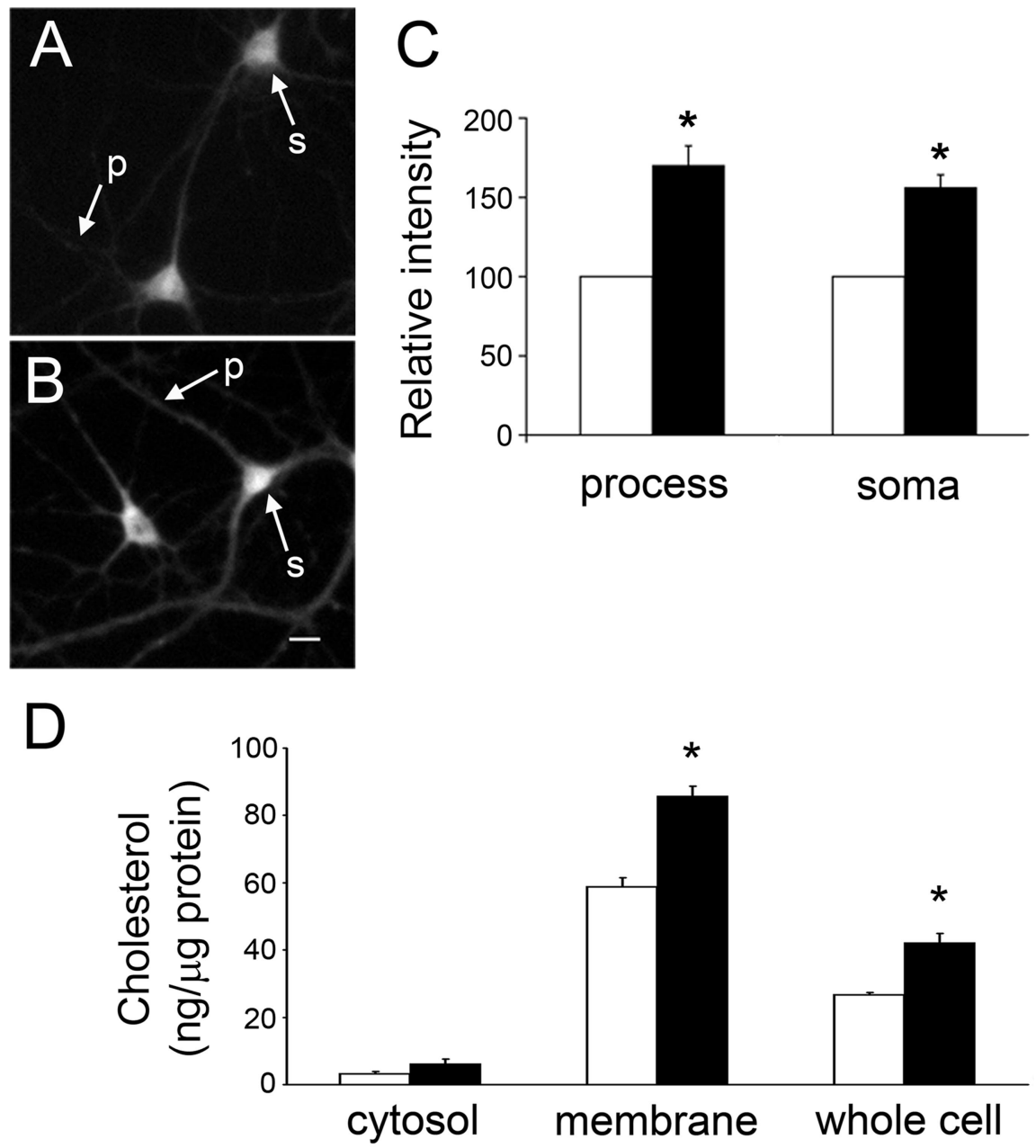

Figure 4. Membrane cholesterol levels increased as hippocampal neurons developed in culture. $\boldsymbol{A}, \boldsymbol{B}$, Filipin labeling of $7(\boldsymbol{A})$ and $21(\boldsymbol{B}) \mathrm{d}$ in culture hippocampal neurons showed intense fluorescence in the soma (s) of neurons in both age groups. The staining extended further into the processes $(p)$ of the older neurons than the younger ones. C, Quantitative analysis of the relative filipin fluorescence intensity in 7 (white bars) and 21 (black bars) $d$ in culture hippocampal neurons. Note the increased filipin intensity in the soma $(s)$ and processes (p) of $21 \mathrm{~d}$ in culture neurons compared with those of $7 \mathrm{~d}$ in culture ones. $D$, Cholesterol quantification in cytosol, membrane, and whole-cell fractions of neurons cultured for 7 (white bars) and 21 (black bars) d by means of Amplex Red analysis. Values were normalized to total protein in these lysates. Each graph displays the mean values \pm SEM and a statistical comparison between 7 and $21 \mathrm{~d}$ in culture cells. * Differs from $7 \mathrm{~d}$ in culture values, $p<0.01$. Scale bar, $20 \mu \mathrm{m}$.

to reduce membrane cholesterol in these cells to equal that of young neurons. Contrastingly, MBCD used at a concentration of $2 \mathrm{mM}$ or higher decreased membrane cholesterol in mature hippocampal neurons to levels comparable to young ones (Fig. 5A). Treated neurons were able to maintain this change in membrane cholesterol for $24 \mathrm{~h}$ (Fig. 5A).

We next determined whether the membrane cholesterol alterations described above cause a change in the susceptibility of mature cultured hippocampal neurons to $\mathrm{A} \beta$-induced calpain activation and subsequent production of the $17 \mathrm{kDa}$ tau fragment. For these experiments, hippocampal neurons cultured for $21 \mathrm{~d}$ were subjected to treatment with MBCD after which they were incubated with $A \beta$. Following the $\mathrm{A} \beta$ treatment, the cells were subjected to immunoblotting using both tau and spectrin antibodies. A $\beta$-treated cells showed reduced full-length tau immunoreactivity accompanied by the appearance of a strong tau immunoreactive band at $17 \mathrm{kDa}$ when compared with either untreated controls or cells treated with MBCD alone (Fig. 5B). However, $21 \mathrm{~d}$ in culture neurons that were incubated in the presence of both MBCD and A $\beta$ maintained full-length tau immunoreactivity similar to controls. Furthermore, mature neurons treated with MBCD followed by $A \beta$ incubation revealed decreased tau immunoreactivity at $17 \mathrm{kDa}$, thus significantly reducing the $17 \mathrm{kDa}$ to full-length tau ratio in these cells compared with those treated with $\mathrm{A} \beta$ alone (Fig. $5 B, C$ ). When these mature lysates were analyzed by immunoblotting with a spectrin antibody, control and MBCDtreated cells contained similar levels of 240 and $150 \mathrm{kDa}$ spectrin (Fig. 5B,C). Con-

peak of $67.9 \pm 0.5 \mathrm{ng} / \mu \mathrm{g}$ protein in P90 rats. Statistical analysis showed that cholesterol levels were also significantly higher in the hippocampi of rats aged P10, P15, and P20 (45 $\pm 1.9,50.7 \pm 3.3$, and $52 \pm 7 \mathrm{ng} / \mu \mathrm{g}$ protein, respectively) than those of young rats aged $\mathrm{P} 1$ and $\mathrm{P} 5(22.8 \pm 5.6$ and $35.1 \pm 0.5 \mathrm{ng} / \mu \mathrm{g}$ protein, respectively). These data provided further support that cholesterol levels in hippocampal neurons were developmentally regulated.

\section{Membrane cholesterol reduction in mature hippocampal neurons decreased their susceptibility to $\mathrm{A} \beta$-induced $17 \mathrm{kDa}$ tau production and calpain activation}

To assess whether membrane cholesterol plays a role in mediating age-dependent differences in the susceptibility of hippocampal neurons to $\mathrm{A} \beta$-mediated calpain activation and $17 \mathrm{kDa}$ tau generation, we performed experiments to decrease membrane cholesterol in mature cells to that of young ones. This was achieved by treating $21 \mathrm{~d}$ in culture hippocampal neurons with MBCD. MBCD lowered membrane cholesterol levels of mature neurons in a dose-dependent manner over a course of $30 \mathrm{~min}$ (Fig. 5A). Concentrations equal to or below $1.5 \mathrm{~mm}$ MBCD failed versely, mature hippocampal neurons cultured in the presence of $\mathrm{A} \beta$ alone had a significantly increased 150 to $240 \mathrm{kDa}$ spectrin ratio compared with controls (Fig. $5 B, C$ ). When these cells were cultured in the presence of both MBCD and $\mathrm{A} \beta$, they showed 240 $\mathrm{kDa}$ full-length spectrin levels comparable to control and MBCD-treated cells with an accompanied decrease in calpaincleaved spectrin at $150 \mathrm{kDa}$ with respect to $\mathrm{A} \beta$-treated cells (Fig. $5 B, C)$. Finally, cell viability in mature neurons that underwent cholesterol modification and $\mathrm{A} \beta$ treatment was analyzed using the cell death assay. The percentage of cell death in mature neurons treated with MBCD alone was not significantly different from control cells, suggesting that this drug was not toxic to cultured neurons at a concentration of $2 \mathrm{~mm}$ (Fig. 5D). As shown previously in Figure $1 I$, cells treated with $\mathrm{A} \beta$ alone showed a marked increase in cell death compared with untreated or MBCD-treated neurons (Fig. 5D). In contrast, hippocampal neurons treated with $\mathrm{MBCD}$ before the addition of preaggregated $\mathrm{A} \beta$ showed a great reduction in $A \beta$-induced toxicity compared with cells treated only with $\mathrm{A} \beta$ (Fig. $5 D$ ). 
A $\beta$-induced calpain activation and 17 $\mathrm{kDa}$ tau generation was increased in young cells after the addition of cholesterol to their membranes

The data described above indicated that reducing membrane cholesterol in mature cultured neurons decreased their susceptibility to $\mathrm{A} \beta$-dependent calpain-mediated tau cleavage and cell death. To further assess the role of cholesterol in these mechanisms, we analyzed to what extent the increase in membrane cholesterol in young neurons to levels comparable to mature cells might affect their vulnerability to $A \beta$ toxicity. The addition of cholesterol was accomplished by using a pharmacological agent that comprises both MBCD and cholesterol (MBCD:CH). $\beta$-Cyclodextrins such as MBCD are able to remove cholesterol from cellular membranes when this steroid is absent in the culture medium, and serve as a vehicle to deliver cholesterol to cell surfaces when complexed with cholesterol (Christian et al., 1997). For these experiments, $7 \mathrm{~d}$ in culture hippocampal neurons were incubated in the presence of increasing concentrations of complexed cholesterol together with $2 \mu \mathrm{g} / \mathrm{ml}$ free cholesterol for $1 \mathrm{~h}$. Our results showed that the incubation of young neurons with MBC$\mathrm{D}: \mathrm{CH}$ complexed cholesterol at concentrations of $30 \mu \mathrm{M}$ or higher increased their membrane cholesterol content to levels equal to that of mature ones (Fig. 6A). We then assessed tau cleavage and calpain activation in MBCD:CH-treated cells to exclude any toxicity of this pharmacological agent. Whole-cell lysates prepared from $7 \mathrm{~d}$ in culture hippocampal neurons treated with MBCD:CH showed strong full-length tau immunoreactivity comparable to untreated controls and cells treated with $\mathrm{A} \beta$ (Fig. $6 B$; see also Fig. 2). While the $17 \mathrm{kDa}$ tau fragment was not detectable in untreated controls or in cells treated with $\mathrm{A} \beta$ alone, an extremely faint, yet quantifiable tau immunoreactive band at an apparent weight of $17 \mathrm{kDa}$ was detected in the MBCD:CH-treated neurons (Fig. 6B). Similarly, no changes in 150 to $240 \mathrm{kDa}$ spectrin ratios were detected under these experimental conditions (Fig. $6 B, D)$. Collectively, these results suggested the MBCD:CH treatment did not induce significant $17 \mathrm{kDa}$ production or calpain activation in these cells. We then examined to what extent pretreatment with MBCD:CH affected the vulnerability of young cultured hippocampal neurons to $A \beta$-induced calpain-mediated tau cleavage. Western blotting of lysates prepared from cells treated with MBCD:CH before the addition of $\mathrm{A} \beta$ revealed a marked enhancement in tau immunoreactivity at $17 \mathrm{kDa}$, resulting in a distinct band at this molecular weight and a significant increase in the $17 \mathrm{kDa}$ to full-length tau ratio (Fig. $6 \mathrm{~B}, \mathrm{C}$ ). This

B
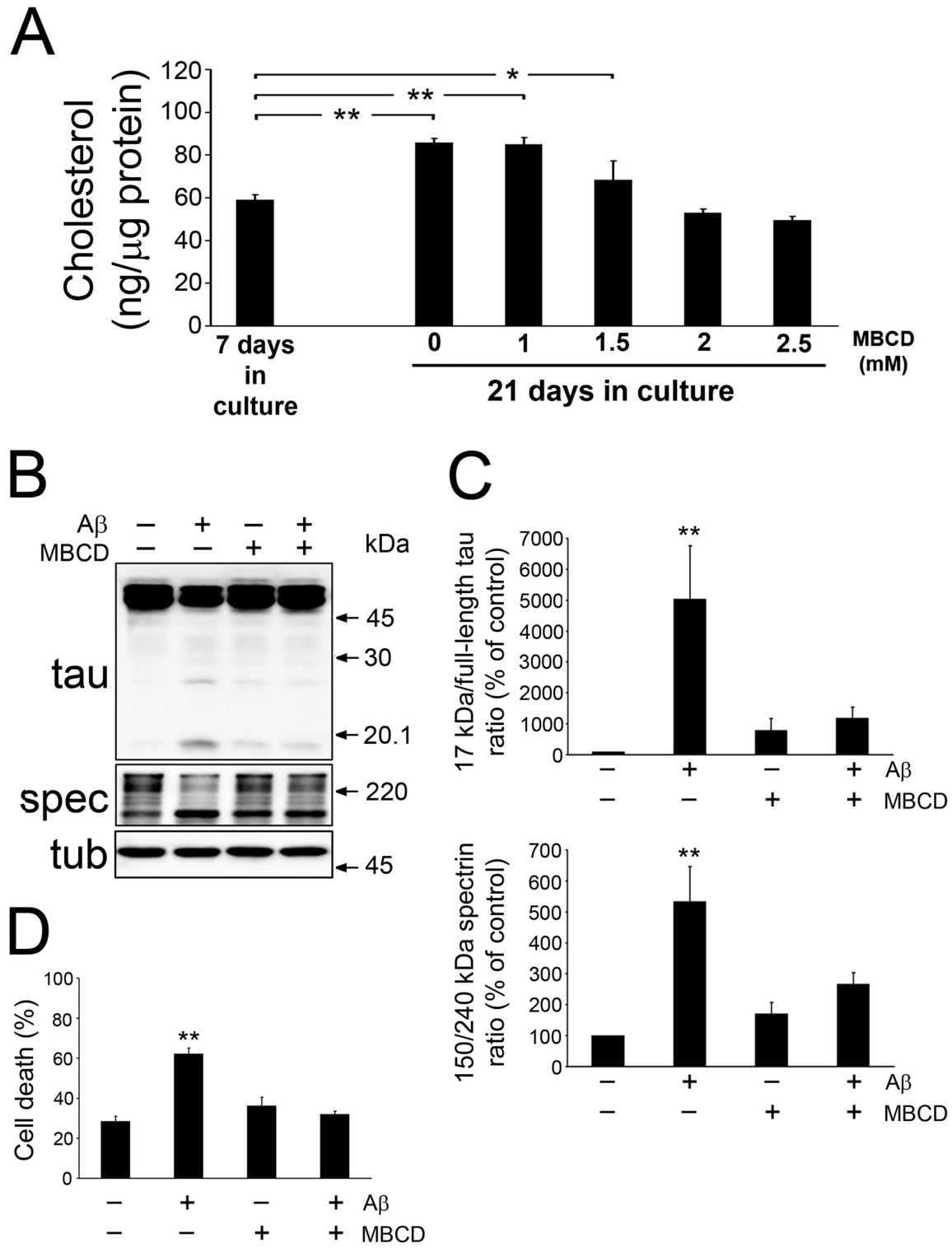

Figure 5. Membrane cholesterol reduction in mature cultured hippocampal neurons decreased their susceptibility to $A \beta$ induced $17 \mathrm{kDa}$ tau production and calpain activation. $\boldsymbol{A}$, Twenty-one days in culture hippocampal neurons were incubated in the presence of increasing doses of MBCD for $30 \mathrm{~min}$. The cells were harvested $24 \mathrm{~h}$ later, and the cholesterol levels in the membrane fractions were analyzed by the Amplex Red cholesterol assay. All values were normalized to total protein in each sample, and statistical analyses were performed between the opposing age and the different doses. Membrane cholesterol levels in mature neurons matched those of young neurons only when treated with at least $2 \mathrm{~mm} \mathrm{MBCD}$. B. Hippocampal neurons cultured for $21 \mathrm{~d}$ were treated with (+) or without (-) 2 mм MBCD, $A \beta$, or both, and whole-cell lysates were prepared $24 \mathrm{~h}$ later. Western blotting of whole-cell lysates was performed using tau (clone tau5) and spectrin antibodies. Tubulin was used as a loading control. The levels of $17 \mathrm{kDa}$ tau fragment and cleaved spectrin were significantly lower in neurons that were treated with MBCD before the addition of $A \beta$. C, Quantitative analysis of the $17 \mathrm{kDa}$ tau fragment and spectrin cleavage in mature cultured hippocampal neurons treated as described above. The $17 \mathrm{kDa}$ densitometry values were calculated as a ratio of full-length tau, whereas spectrin values represent the ratio between full-length $240 \mathrm{kDa}$ and calpain-cleaved $150 \mathrm{kDa}$ spectrin bands. Control neurons were considered 100\%.D, Quantification of cell death in mature neurons treated as described in $\boldsymbol{B}$ in which the values are expressed as a percentage of total cells. The data in the graphs represent the mean \pm SEM obtained from at least three independent experiments. * ${ }^{\text {Differs }}$ from untreated controls, $p<0.05{ }^{* *} p<0.01$.

pattern was also apparent when blotting with a spectrin antibody for the assessment of calpain activity. Full-length spectrin immunoreactivity at $240 \mathrm{kDa}$ was reduced and a concomitant increase in the calpain-cleaved spectrin immunoreactivity at $150 \mathrm{kDa}$ was detected in young neurons treated with both MBCD:CH and $\mathrm{A} \beta$ when compared with untreated controls or those treated with MBCD:CH alone (Fig. 6B, C). These changes in the generation of the $17 \mathrm{kDa}$ tau fragment and calpain activation were accompa- 


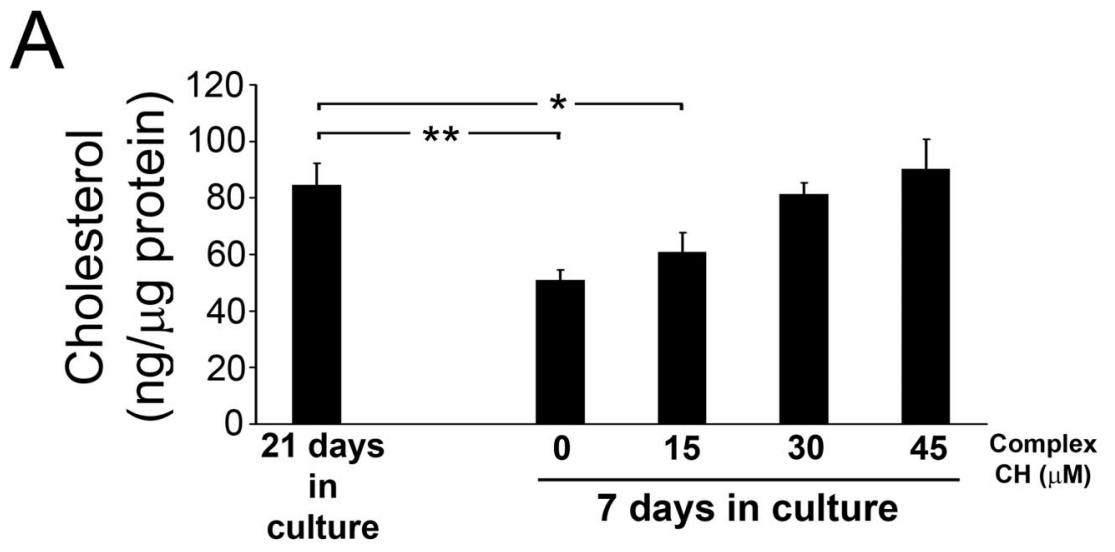

B
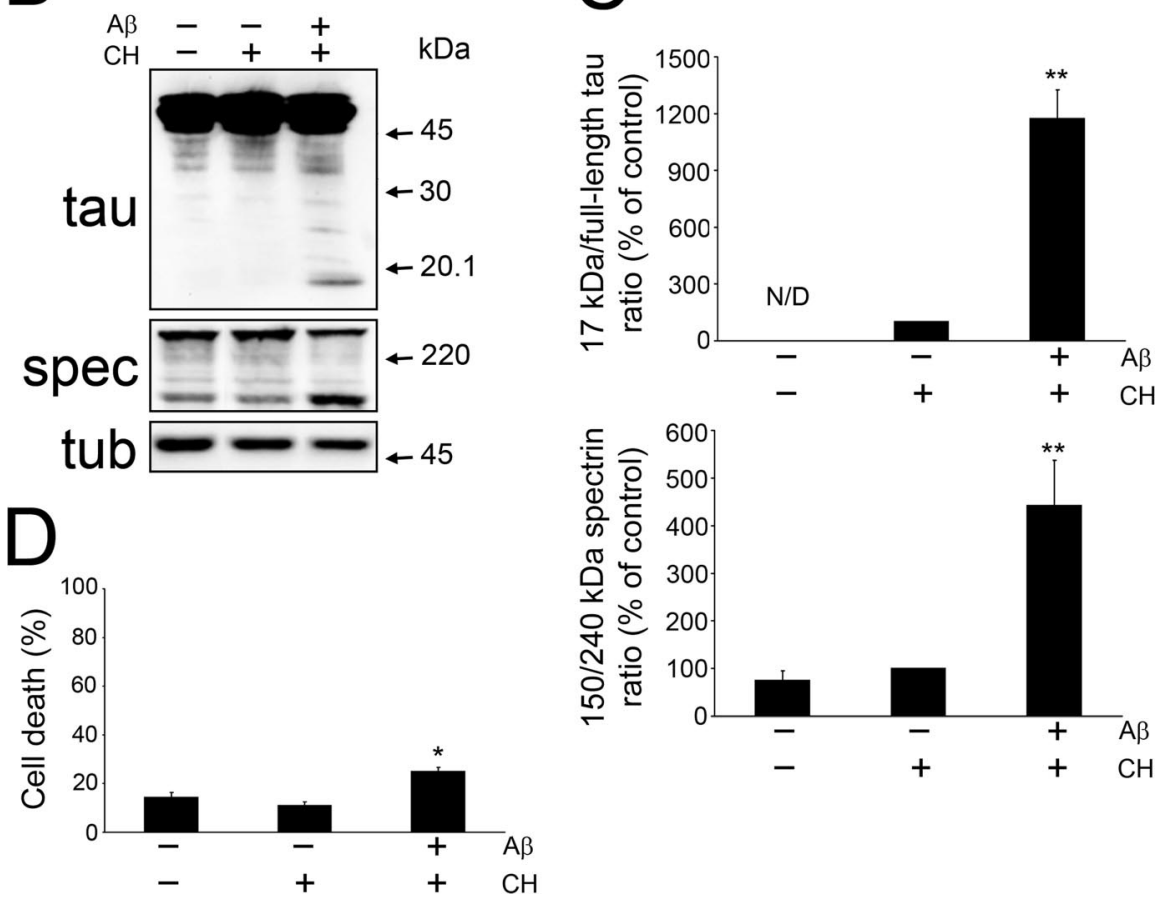

Figure 6. The addition of cholesterol to the membrane of young hippocampal neurons increased their vulnerability to $A \beta$ induced $17 \mathrm{kDa}$ generation and calpain activation. $A$, Seven days in culture neurons were treated with increasing concentrations of MBCD:CH plus $2 \mu \mathrm{g} / \mathrm{ml}$ free cholesterol for $1 \mathrm{~h}$. The cells were harvested after treatment, and membrane fraction cholesterol levels were assessed using the Amplex Red cholesterol assay. All values were normalized to total protein in each sample, and statistical analyses were performed between the opposing age and the different doses. Membrane cholesterol levels in young hippocampal neurons matched those of mature neurons only when treated with at least $30 \mu \mathrm{m}$ complexed cholesterol. $\boldsymbol{B}$, Whole-cell lysates were prepared from $7 \mathrm{~d}$ in culture neurons treated in the absence $(-)$ or presence $(+)$ of $30 \mu \mathrm{m}$ complexed cholesterol, $A \beta$, or both. Western blotting was performed using tau (clone tau5) and spectrin antibodies. Tubulin was used as a loading control. The levels of the $17 \mathrm{kDa}$ tau fragment and cleaved spectrin were significantly higher in neurons that were treated with complexed cholesterol before the addition of $A \beta$. C, Quantitative analysis of the $17 \mathrm{kDa}$ tau fragment and spectrin cleavage in mature cultured hippocampal neurons treated as described in $\boldsymbol{B}$. The $17 \mathrm{kDa}$ densitometry values were calculated as a ratio of full-length tau, whereas spectrin values represent the ratio between full-length $240 \mathrm{kDa}$ and calpain-cleaved $150 \mathrm{kDa}$ spectrin bands. Cholesterol-treated neurons were considered 100\%. D, Quantification of cell death in mature neurons treated as described in $\boldsymbol{B}$ in which the values are expressed as a percentage of total cells. The data in the graphs represent the mean \pm SEM obtained from at least three independent experiments. ${ }^{*}$ Differs from cholesterol-treated controls, $p<0.05 ;{ }^{* *} p<0.01$. N/D, Not detectable.

nied with increased vulnerability of these cells to $\mathrm{A} \beta$. Thus, quantification of cell death in neurons treated with both MBCD:CH and $A \beta$ revealed a significant increase in cell death compared with untreated controls and cells treated with only MBCD:CH (Fig. 6D; see also Fig. 1I).
Changes in membrane cholesterol levels altered intracellular $\mathrm{Ca}^{2+}$ in response to A $\boldsymbol{\beta}$ treatment

The data presented herein suggested that an age-dependent increase in membrane cholesterol levels might enhance the susceptibility of hippocampal neurons to $\mathrm{A} \beta$ induced calpain activation and $17 \mathrm{kDa}$ tau production. However, a link between membrane cholesterol and calpain activation has yet to be established. It has been previously shown that $\mathrm{A} \beta$-mediated calpain activation in cultured hippocampal neurons occurs through increased $\mathrm{Ca}^{2+}$ influx, a phenomenon that has been greatly implicated in $\mathrm{AD}$ pathogenesis (Kelly and Ferreira, 2006) [for review, see Green et al. (2007), Bezprozvanny and Mattson (2008), and Bojarski et al. (2008)]. Thus, we used fura-2 imaging, a common technique for live $\mathrm{Ca}^{2+}$ assessment, to determine to what extent altering membrane cholesterol levels in cultured hippocampal neurons affects $A \beta$-induced $\mathrm{Ca}^{2+}$ influx (Murphy and Miller, 1989; Brewer et al., 2006; Resende et al., 2007; Kato-Negishi and Kawahara, 2008). For these experiments, mature cells were loaded with the fura- $2 \mathrm{AM} \mathrm{Ca}^{2+}$ indicator and the basal intracellular $\mathrm{Ca}^{2+}$ concentration determined using the MetaFluor Image Analysis software as described (see Materials and Methods). Normal baseline $\mathrm{Ca}^{2+}$ levels $(112.9 \pm 8.4 \mathrm{nM})$ were detected in untreated and MBCD-treated mature neurons (Fig. 7A) (Mattson et al., 1993; Guo et al., 1999; Resende et al., 2007; Kato-Negishi and Kawahara, 2008). In contrast, the addition of the $\mathrm{A} \beta$ peptide to these cells resulted in increased intracellular $\mathrm{Ca}^{2+}$ by nearly three times that of controls (284.7 $\pm 35.5 \mathrm{~nm}$ ) (Fig. $7 A$ ). This increase in basal calcium concentration was completely prevented when mature hippocampal neurons were treated with MBCD before the addition of $\mathrm{A} \beta$ (Fig. 7A). These experiments were repeated in young neurons incubated with MBCD:CH, $\mathrm{A} \beta$, or both. Fura-2 imaging of untreated and MBCD:CHtreated young neuron controls exhibited levels of intracellular $\mathrm{Ca}^{2+}$ similar to that of untreated mature cells (Fig. $7 B$ ). However, unlike the mature cells, $\mathrm{A} \beta$ treatment of young neurons did not significantly increase $\mathrm{Ca}^{2+}$ levels in these cells $(117.5 \pm 9.6 \mathrm{nM})$. In contrast, a marked increase in intracellular $\mathrm{Ca}^{2+}$ levels was detected when membrane cholesterol was increased before the addition of $A \beta(161.4 \pm 16.5 \mathrm{~nm})$ (Fig. $7 B$ ). These results suggested that membrane cholesterol might modulate the vulnerability of cultured hippocampal neurons to $\mathrm{A} \beta$ toxicity by affecting $\mathrm{A} \beta$-induced $\mathrm{Ca}^{2+}$ influx in these cells. 


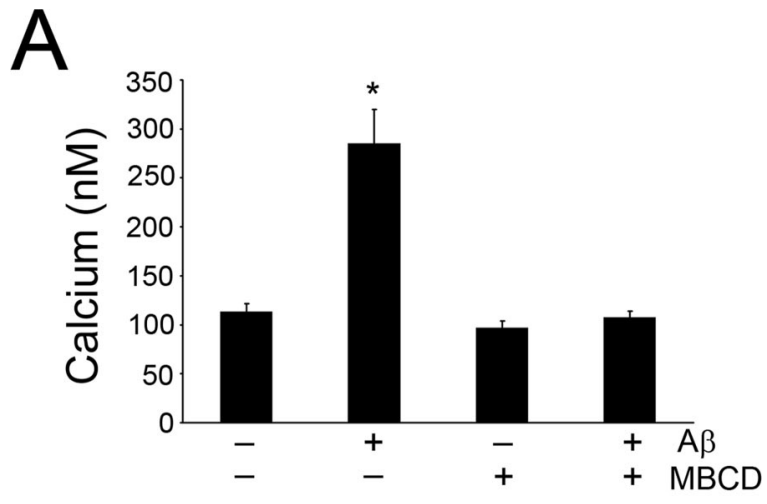

B

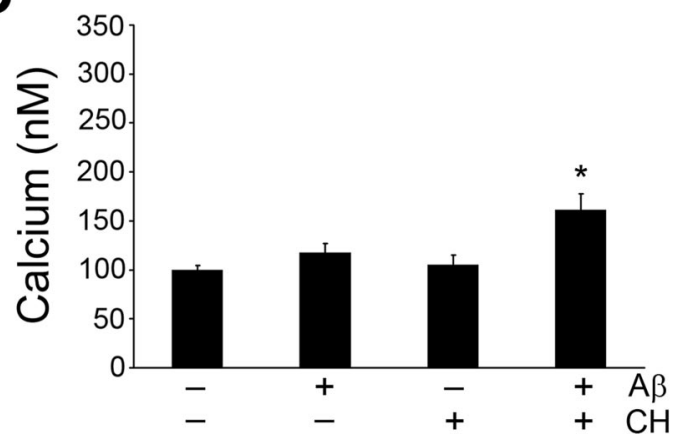

Figure 7. Effects of changes in membrane cholesterol on intracellular $\mathrm{Ca}^{2+}$ levels in cultured hippocampal neurons. $\boldsymbol{A}, \boldsymbol{B}$, Intracellular $\mathrm{Ca}^{2+}$ levels were measured in fura-2-loaded hippocampal neurons after baselines had stabilized. Fura-2 loading and recording were performed in mature neurons after treatment with $(+)$ or without $(-) A \beta, M B C D$, or both $(A)$ and in young cells that were incubated in the presence $(+)$ or absence $(-)$ of $A \beta, M B C D: C H$, or both $(B)$. The values represent the mean \pm SEM for cells imaged in at least 10 fields per condition. *Differs from untreated controls, $p<0.01$.

\section{Discussion}

The results described above indicated that mature cultured hippocampal neurons were more susceptible to $\mathrm{A} \beta$-induced generation of the neurotoxic $17 \mathrm{kDa}$ tau fragment than young ones. In addition, they suggested that this increased $17 \mathrm{kDa}$ production in mature neurons was due to age-dependent differences in calpain activation. Furthermore, our data identified membrane cholesterol as a potential link between aging, $\mathrm{A} \beta, \mathrm{Ca}^{2+}$ homeostasis, and tau pathology in hippocampal neurons.

In the past decade, it has become increasingly clear that tau plays an essential role in $\mathrm{A} \beta$-mediated toxicity in central neurons. The initial report showing that tau-depleted hippocampal neurons did not degenerate in the presence of $\mathrm{A} \beta$ was followed by behavioral studies indicating that cognitive impairment was reduced in APP transgenic mice that did not express tau when compared with tau-expressing ones (Rapoport et al., 2002; Roberson et al., 2007). The mechanisms underlying $A \beta$-mediated tau toxicity include increased phosphorylation and the proteolytic processing of this microtubule-associated protein (Novak et al., 1993; Chung et al., 2001; Gamblin et al., 2003; Park and Ferreira, 2005; Wei et al., 2008). Caspase-3- and calpain-mediated proteolysis enhanced tau toxicity by regulating its aggregation properties or by generating a $17 \mathrm{kDa}$ toxic fragment, respectively (Park and Ferreira, 2005; Park et al., 2007). The present study provided evidence suggesting that the calpain-mediated tau cleavage leading to the generation of the $17 \mathrm{kDa}$ tau fragment was age dependent. These results are in agreement with previous studies that showed changes in the susceptibility of neurons to $\mathrm{A} \beta$ as they mature. Thus, in the presence of $\mathrm{A} \beta$, modest changes in tau phosphorylation were detected in young neurons compared with untreated controls. On the other hand, $A \beta$ significantly increased tau phosphorylation at sites commonly found in neurofibrillary tangles in mature cultured neurons (Ferreira et al., 1997). Furthermore, different signal transduction pathways seemed to be activated by $\mathrm{A} \beta$ in young and mature cultured neurons. While glycogen synthase kinase $3 \beta$ and cyclin-dependent kinase 5 were the main kinases activated by this peptide in young neurons, extracellular signal-regulated kinases 1 and 2 were highly activated in mature hippocampal neurons (Takashima et al., 1993; Ferreira et al., 1997; Alvarez et al., 1999; Rapoport and Ferreira, 2000). The mechanisms underlying different susceptibilities to $\mathrm{A} \beta$-induced posttranslational tau modifications as neurons age remain poorly understood. These differences could be developmentally regulated at the level of tau. This microtubuleassociated protein undergoes age-dependent alternative splicing in central neurons that develop in situ and in culture (Kosik et al., 1989; Ferreira et al., 1997). While young neurons express tau isoforms lacking exons 2, 3 and 10 (fetal isoforms), mature neurons express mainly adult isoforms containing all three exons (mature isoforms). In the case of $\mathrm{A} \beta$-dependent $17 \mathrm{kDa}$ tau generation, however, our results showed that both fetal and adult recombinant tau isoforms could be cleaved by calpain in vitro, and that the proteolytic products from both reactions included a tau immunoreactive band at an apparent molecular weight of 17 $\mathrm{kDa}$. These results suggested that age-related differences in $\mathrm{A} \beta$ mediated $17 \mathrm{kDa}$ tau generation detected in cultured hippocampal neurons were independent of tau isoform expression. Alternatively, developmental regulation of $\mathrm{A} \beta$-induced calpain cleavage of tau might be mediated by changes in expression of this protease or its endogenous inhibitor, calpastatin, since previous reports indicated that the expression of these proteins changed with age (Kenessey et al., 1990; Ibrahim et al., 1994; Ma et al., 1999; Manya et al., 2002). Immunoblotting of lysates obtained from young and mature cultured hippocampal neurons did not reveal significant changes in the ratio of calpain to calpastatin in these cells. These data suggested that age-dependent differences in $\mathrm{A} \beta$-induced calpain activation were regulated, at least in part, upstream of this enzyme in our model system.

Multiple reports have suggested that calpain activation takes place at the membrane (Coolican and Hathaway, 1984; Pontremoli et al., 1985; Saido et al., 1992, 1993; Tompa et al., 2001; Fernández-Montalván et al., 2006). Several lines of evidence have also suggested that membrane cholesterol might be an upstream regulator of the activation of calpain under different experimental conditions. First, the organization of the membrane into segregated microdomains, which plays an essential role in signal transduction, lipid sorting, membrane fusion, cytoskeletal organization, and protein trafficking and turnover, seemed to be modulated by cholesterol (Simons and van Meer, 1988; Simons and Ikonen, 1997, 2000; Brown and London, 1998a,b; Laux et al., 2000; Caroni, 2001; Chamberlain et al., 2001; Galbiati et al., 2001; Ikonen, 2001; Lang et al., 2001; Sharma et al., 2003). Second, manipulating membrane cholesterol levels has been shown to alter the sensitivity of cells to $\mathrm{Ca}^{2+}$ influx, a process critical for the activation of calpain (Bastiaanse et al., 1994). Our results provided further support for such a role. Thus, membrane cholesterol levels were significantly higher in mature neurons when compared with young ones. Furthermore, a decrease in the susceptibility of mature neurons to $\mathrm{A} \beta$-dependent $\mathrm{Ca}^{2+}$ influx leading to calpain activation, tau cleavage, and cell death was observed after their membrane cholesterol levels had been reduced 
by MBCD to that of young neurons. Conversely in young neurons, the addition of membrane cholesterol to levels similar to mature ones increased their susceptibility to $\mathrm{A} \beta$ toxicity as it pertained to $\mathrm{Ca}^{2+}$ influx, calpain activation, $17 \mathrm{kDa}$ tau production, and cell death. However, these cellular processes were not as elevated as those observed in $\mathrm{A} \beta$-treated mature neurons. These differences might be related to synapse formation in hippocampal neurons as they age in culture. Previous studies have shown that albeit synapse formation occurs in this culture system as early as $5 \mathrm{~d}$ after plating, the expression of synaptic markers and the number of synaptic contacts formed between hippocampal neurons in culture increases as these cells age (Fletcher et al., $1991,1994)$. Furthermore, our lab has shown that $\mathrm{A} \beta$-induced changes in $\mathrm{Ca}^{2+}$ homeostasis leading to calpain activation is dependent specifically on NMDA receptors (Kelly and Ferreira, 2006). The expression of these receptors and their associated proteins has also been shown to be developmentally regulated, with overall increased expression of these proteins in older cells (Sans et al., 2000; Besshoh et al., 2007). A more detailed analysis of the developmental regulation of these proteins, as well as how the expression of these proteins might change with membrane cholesterol modifications, is required to gain further insight into the mechanism behind age-dependent $\mathrm{A} \beta$ toxicity.

It is also important to note that the cholesterol modifying pharmacological agents (MBCD and MBCD:CH) used in this study have been shown to target cholesterol directly and specifically at the membrane of hippocampal neurons. However, we cannot exclude the possibility that these cholesterol level modifications might regulate $\mathrm{A} \beta$-mediated calpain activation due to alterations of membrane functions other than localized signaling. Regardless of the mechanisms, our data identified cholesterol as a potential link between aging and tau pathology in the context of AD. Several studies have started to address the effect of statins, cholesterol-lowering drugs that target 3-hydroxy-3-methylglutaryl-CoA reductase at the rate-limiting step of the cholesterol synthesis pathway, on the risk for dementia [for review, see Eckert et al. (2005), Wolozin et al. (2006), Kuller (2007), and Orr (2008)]. However, the results obtained have been inconclusive probably because of the pleiotropic mechanisms of actions of these drugs [for review, see Vaughan (2003), Miida et al. (2004), Crisby (2006), Cimino et al. (2007), and Miida et al. (2007)]. Further investigation will be needed to determine to what extent this lipid could become a target for therapeutic intervention in $\mathrm{AD}$ and related disorders.

\section{References}

Alvarez A, Toro R, Cáceres A, Maccioni RB (1999) Inhibition of tau phosphorylating protein kinase cdk5 prevents beta-amyloid-induced neuronal death. FEBS Lett 459:421-426.

Aras MA, Hartnett KA, Aizenman E (2008) Assessment of cell viability in primary neuronal cultures. Curr Protoc Neurosci Chapter 7:Unit 7.18.

Arispe N, Doh M (2002) Plasma membrane cholesterol controls the cytotoxicity of Alzheimer's disease AbetaP (1-40) and (1-42) peptides. FASEB J 16:1526-1536.

Bastiaanse EM, Atsma DE, Kuijpers MM, Van der Laarse A (1994) The effect of sarcolemmal cholesterol content on intracellular calcium ion concentration in cultured cardiomyocytes. Arch Biochem Biophys 313:58-63.

Bensadoun A, Weinstein D (1976) Assay of proteins in the presence of interfering materials. Anal Biochem 70:241-250.

Benuck M, Banay-Schwartz M, DeGuzman T, Lajtha A (1996) Changes in brain protease activity in aging. J Neurochem 67:2019-2029.

Besshoh S, Chen S, Brown IR, Gurd JW (2007) Developmental changes in the association of NMDA receptors with lipid rafts. J Neurosci Res 85:1876-1883.

Bezprozvanny I, Mattson MP (2008) Neuronal calcium mishandling and the pathogenesis of Alzheimer's disease. Trends Neurosci 31:454-463.
Black L, Berenbaum MC (1964) Factors affecting the dye exclusion test for cell viability. Exp Cell Res 35:9-13.

Bojarski L, Herms J, Kuznicki J (2008) Calcium dysregulation in Alzheimer's disease. Neurochem Int 52:621-633.

Bottenstein JE, Sato GH (1979) Growth of a rat neuroblastoma cell line in serum-free supplemented medium. Proc Natl Acad Sci USA 76:514-517.

Brewer GJ, Reichensperger JD, Brinton RD (2006) Prevention of age-related dysregulation of calcium dynamics by estrogen in neurons. Neurobiol Aging 27:306-317.

Brown DA, London E (1998a) Structure and origin of ordered lipid domains in biological membranes. J Membr Biol 164:103-114.

Brown DA, London E (1998b) Functions of lipid rafts in biological membranes. Annu Rev Cell Dev Biol 14:111-136.

Caroni P (2001) New EMBO members' review: actin cytoskeleton regulation through modulation of $\mathrm{PI}(4,5) \mathrm{P}(2)$ rafts. EMBO J 20:4332-4336.

Chamberlain LH, Burgoyne RD, Gould GW (2001) SNARE proteins are highly enriched in lipid rafts in PC12 cells: implications for the spatial control of exocytosis. Proc Natl Acad Sci U S A 98:5619-5624.

Christian AE, Haynes MP, Phillips MC, Rothblat GH (1997) Use of cyclodextrins for manipulating cellular cholesterol content. J Lipid Res 38:2264-2272.

Chung CW, Song YH, Kim IK, Yoon WJ, Ryu BR, Jo DG, Woo HN, Kwon YK, Kim HH, Gwag BJ, Mook-Jung IH, Jung YK (2001) Proapoptotic effects of tau cleavage product generated by caspase-3. Neurobiol Dis 8:162-172.

Cimino M, Gelosa P, Gianella A, Nobili E, Tremoli E, Sironi L (2007) Statins: multiple mechanisms of action in the ischemic brain. Neuroscientist 13:208-213.

Coolican SA, Hathaway DR (1984) Effect of L-alpha-phosphatidylinositol on a vascular smooth muscle $\mathrm{Ca} 2+$-dependent protease. Reduction of the $\mathrm{Ca} 2+$ requirement for autolysis. J Biol Chem 259:11627-11630.

Crisby M (2006) The role of pleiotropic effects of statins in dementia. Acta Neurol Scand Suppl 185:115-118.

Czogalla A, Sikorski AF (2005) Spectrin and calpain: a 'target' and a 'sniper' in the pathology of neuronal cells. Cell Mol Life Sci 62:1913-1924.

Damke H, Baba T, Warnock DE, Schmid SL (1994) Induction of mutant dynamin specifically blocks endocytic coated vesicle formation. J Cell Biol 127:915-934.

Eckert GP, Wood WG, Müller WE (2005) Statins: drugs for Alzheimer's disease? J Neural Transm 112:1057-1071.

Ehehalt R, Keller P, Haass C, Thiele C, Simons K (2003) Amyloidogenic processing of the Alzheimer beta-amyloid precursor protein depends on lipid rafts. J Cell Biol 160:113-123.

Fernández-Montalván A, Assfalg-Machleidt I, Pfeiler D, Fritz H, Jochum M, Machleidt W (2006) Mu-calpain binds to lipid bilayers via the exposed hydrophobic surface of its $\mathrm{Ca} 2+$-activated conformation. Biol Chem 387:617-627.

Ferreira A, Lu Q, Orecchio L, Kosik KS (1997) Selective phosphorylation of adult tau isoforms in mature hippocampal neurons exposed to fibrillar A beta. Mol Cell Neurosci 9:220-234.

Fletcher TL, Cameron P, De Camilli P, Banker G (1991) The distribution of synapsin I and synaptophysin in hippocampal neurons developing in culture. J Neurosci 11:1617-1626.

Fletcher TL, De Camilli P, Banker G (1994) Synaptogenesis in hippocampal cultures: evidence indicating that axons and dendrites become competent to form synapses at different stages of neuronal development. J Neurosci 14:6695-6706.

Foradori CD, Werner SB, Sandau US, Clapp TR, Handa RJ (2007) Activation of the androgen receptor alters the intracellular calcium response to glutamate in primary hippocampal neurons and modulates sarco/endoplasmic reticulum calcium ATPase 2 transcription. Neuroscience 149:155-164.

Galbiati F, Razani B, Lisanti MP (2001) Emerging themes in lipid rafts and caveolae. Cell 106:403-411.

Gamblin TC, Chen F, Zambrano A, Abraha A, Lagalwar S, Guillozet AL, Lu M, Fu Y, Garcia-Sierra F, LaPointe N, Miller R, Berry RW, Binder LI, Cryns VL (2003) Caspase cleavage of tau: linking amyloid and neurofibrillary tangles in Alzheimer's disease. Proc Natl Acad Sci US A 100:10032-10037.

Glenner GG, Wong CW (1984) Alzheimer's disease: initial report of the purification and characterization of a novel cerebrovascular amyloid protein. Biochem Biophys Res Commun 120:885-890. 
Goslin K, Asmussen H, Banker G (1998) Rat hippocampal neurons in lowdensity culture. In: Culturing nerve cells, Ed 2 (Banker G, Goslin K, eds), pp 339-357. Cambridge, MA: MIT.

Green KN, Smith IF, Laferla FM (2007) Role of calcium in the pathogenesis of Alzheimer's disease and transgenic models. Subcell Biochem 45:507-521.

Guo Q, Fu W, Sopher BL, Miller MW, Ware CB, Martin GM, Mattson MP (1999) Increased vulnerability of hippocampal neurons to excitotoxic necrosis in presenilin-1 mutant knock-in mice. Nat Med 5:101-106.

Ibrahim M, Upreti RK, Kidwai AM (1994) Calpain from rat intestinal epithelial cells: age-dependent dynamics during cell differentiation. Mol Cell Biochem 131:49-59.

Igbavboa U, Avdulov NA, Schroeder F, Wood WG (1996) Increasing age alters transbilayer fluidity and cholesterol asymmetry in synaptic plasma membranes of mice. J Neurochem 66:1717-1725.

Igbavboa U, Eckert GP, Malo TM, Studniski AE, Johnson LN, Yamamoto N, Kobayashi M, Fujita SC, Appel TR, Müller WE, Wood WG, Yanagisawa K (2005) Murine synaptosomal lipid raft protein and lipid composition are altered by expression of human apoE 3 and 4 and by increasing age. J Neurol Sci 229-230:225-232.

Ikonen E (2001) Roles of lipid rafts in membrane transport. Curr Opin Cell Biol 13:470-477.

Imahori K, Hoshi M, Ishiguro K, Sato K, Takahashi M, Shiurba R, Yamaguchi H, Takashima A, Uchida T (1998) Possible role of tau protein kinases in pathogenesis of Alzheimer's disease. Neurobiol Aging 19:S93-S98.

Kato-Negishi M, Kawahara M (2008) Neurosteroids block the increase in intracellular calcium level induced by Alzheimer's beta-amyloid protein in long-term cultured rat hippocampal neurons. Neuropsychiatr Dis Treat 4:209-218.

Kelly BL, Ferreira A (2006) beta-Amyloid-induced dynamin 1 degradation is mediated by $\mathrm{N}$-methyl- $\mathrm{D}$-aspartate receptors in hippocampal neurons. J Biol Chem 281:28079-28089.

Kelly BL, Ferreira A (2007) Beta-amyloid disrupted synaptic vesicle endocytosis in cultured hippocampal neurons. Neuroscience 147:60-70.

Kelly BL, Vassar R, Ferreira A (2005) Beta-amyloid-induced dynamin 1 depletion in hippocampal neurons. A potential mechanism for early cognitive decline in Alzheimer disease. J Biol Chem 280:31746-31753.

Kenessey A, Banay-Schwartz M, DeGuzman T, Lajtha A (1990) Calpain II activity and calpastatin content in brain regions of 3- and 24-month-old rats. Neurochem Res 15:243-249.

Kosik KS, Joachim CL, Selkoe DJ (1986) Microtubule-associated protein tau (tau) is a major antigenic component of paired helical filaments in Alzheimer disease. Proc Natl Acad Sci U S A 83:4044-4048.

Kosik KS, Orecchio LD, Bakalis S, Neve RL (1989) Developmentally regulated expression of specific tau sequences. Neuron 2:1389-1397.

Kuller LH (2007) Statins and dementia. Curr Atheroscler Rep 9:154-161.

Laemmli UK (1970) Cleavage of structural proteins during the assembly of the head of bacteriophage T4. Nature 227:680-685.

Lang T, Bruns D, Wenzel D, Riedel D, Holroyd P, Thiele C, Jahn R (2001) SNAREs are concentrated in cholesterol-dependent clusters that define docking and fusion sites for exocytosis. EMBO J 20:2202-2213.

Laux T, Fukami K, Thelen M, Golub T, Frey D, Caroni P (2000) GAP43, MARCKS, and CAP23 modulate $\mathrm{PI}(4,5) \mathrm{P}(2)$ at plasmalemmal rafts, and regulate cell cortex actin dynamics through a common mechanism. J Cell Biol 149:1455-1472.

Lee VM (1996) Regulation of tau phosphorylation in Alzheimer's disease. Ann N Y Acad Sci 777:107-113.

Lowry OH, Rosebrough NJ, Farr AL, Randall RJ (1951) Protein measurement with the Folin phenol reagent. J Biol Chem 193:265-275.

Ma H, Hata I, Shih M, Fukiage C, Nakamura Y, Azuma M, Shearer TR (1999) Lp82 is the dominant form of calpain in young mouse lens. Exp Eye Res 68:447-456.

Manya H, Inomata M, Fujimori T, Dohmae N, Sato Y, Takio K, Nabeshima Y, Endo T (2002) Klotho protein deficiency leads to overactivation of mucalpain. J Biol Chem 277:35503-35508.

Mattson MP, Lovell MA, Ehmann WD, Markesbery WR (1993) Comparison of the effects of elevated intracellular aluminum and calcium levels on neuronal survival and tau immunoreactivity. Brain Res 602:21-31.

Miida T, Hirayama S, Nakamura Y (2004) Cholesterol-independent effects of statins and new therapeutic targets: ischemic stroke and dementia. J Atheroscler Thromb 11:253-264.

Miida T, Takahashi A, Ikeuchi T (2007) Prevention of stroke and dementia by statin therapy: experimental and clinical evidence of their pleiotropic effects. Pharmacol Ther 113:378-393.

Murphy SN, Miller RJ (1989) Two distinct quisqualate receptors regulate $\mathrm{Ca} 2+$ homeostasis in hippocampal neurons in vitro. Mol Pharmacol 35:671-680.

Novak M, Kabat J, Wischik CM (1993) Molecular characterization of the minimal protease resistant tau unit of the Alzheimer's disease paired helical filament. EMBO J 12:365-370.

Orr JD (2008) Statins in the spectrum of neurologic disease. Curr Atheroscler Rep 10:11-18.

Park SY, Ferreira A (2005) The generation of a $17 \mathrm{kDa}$ neurotoxic fragment: an alternative mechanism by which tau mediates $\beta$-amyloid-induced neurodegeneration. J Neurosci 25:5365-5375.

Park SY, Tournell C, Sinjoanu RC, Ferreira A (2007) Caspase-3- and calpain-mediated tau cleavage are differentially prevented by estrogen and testosterone in beta-amyloid-treated hippocampal neurons. Neuroscience 144:119-127.

Pevalova M, Filipcik P, Novak M, Avila J, Iqbal K (2006) Post-translational modifications of tau protein. Bratisl Lek Listy 107:346-353.

Pontremoli S, Salamino F, Sparatore B, Michetti M, Sacco O, Melloni E (1985) Following association to the membrane, human erythrocyte procalpain is converted and released as fully active calpain. Biochim Biophys Acta 831:335-339.

Pooler AM, Xi SC, Wurtman RJ (2006) The 3-hydroxy-3-methylglutaryl co-enzyme A reductase inhibitor pravastatin enhances neurite outgrowth in hippocampal neurons. J Neurochem 97:716-723.

Rapoport M, Ferreira A (2000) PD98059 prevents neurite degeneration induced by fibrillar beta-amyloid in mature hippocampal neurons. J Neurochem 74:125-133.

Rapoport M, Dawson HN, Binder LI, Vitek MP, Ferreira A (2002) Tau is essential to beta-amyloid-induced neurotoxicity. Proc Natl Acad Sci U S A 99:6364-6369.

Resende R, Pereira C, Agostinho P, Vieira AP, Malva JO, Oliveira CR (2007) Susceptibility of hippocampal neurons to Abeta peptide toxicity is associated with perturbation of Ca2 + homeostasis. Brain Res 1143:11-21.

Roberson ED, Scearce-Levie K, Palop JJ, Yan F, Cheng IH, Wu T, Gerstein H, Yu GQ, Mucke L (2007) Reducing endogenous tau ameliorates amyloid beta-induced deficits in an Alzheimer's disease mouse model. Science 316:750-754.

Saido TC, Shibata M, Takenawa T, Murofushi H, Suzuki K (1992) Positive regulation of mu-calpain action by polyphosphoinositides. J Biol Chem 267:24585-24590.

Saido TC, Suzuki H, Yamazaki H, Tanoue K, Suzuki K (1993) In situ capture of mu-calpain activation in platelets. J Biol Chem 268:7422-7426.

Sans N, Petralia RS, Wang YX, Blahos J 2nd, Hell JW, Wenthold RJ (2000) A developmental change in NMDA receptor-associated proteins at hippocampal synapses. J Neurosci 20:1260-1271.

Selkoe DJ (1994) Cell biology of the amyloid beta-protein precursor and the mechanism of Alzheimer's disease. Annu Rev Cell Biol 10:373-403.

Sharma DK, Choudhury A, Singh RD, Wheatley CL, Marks DL, Pagano RE (2003) Glycosphingolipids internalized via caveolar-related endocytosis rapidly merge with the clathrin pathway in early endosomes and form microdomains for recycling. J Biol Chem 278:7564-7572.

Simons K, Ikonen E (1997) Functional rafts in cell membranes. Nature 387:569-572.

Simons K, Ikonen E (2000) How cells handle cholesterol. Science 290:1721-1726.

Simons K, van Meer G (1988) Lipid sorting in epithelial cells. Biochemistry 27:6197-6202.

Sponne I, Fifre A, Koziel V, Oster T, Olivier JL, Pillot T (2004) Membrane cholesterol interferes with neuronal apoptosis induced by soluble oligomers but not fibrils of amyloid-beta peptide. FASEB J 18:836-838.

Subasinghe S, Unabia S, Barrow CJ, Mok SS, Aguilar MI, Small DH (2003) Cholesterol is necessary both for the toxic effect of Abeta peptides on vascular smooth muscle cells and for Abeta binding to vascular smooth muscle cell membranes. J Neurochem 84:471-479.

Sun DA, Sombati S, Blair RE, DeLorenzo RJ (2004) Long-lasting alterations in neuronal calcium homeostasis in an in vitro model of stroke-induced epilepsy. Cell Calcium 35:155-163.

Takashima A (2006) GSK-3 is essential in the pathogenesis of Alzheimer's disease. J Alzheimers Dis 9:309-317.

Takashima A, Noguchi K, Sato K, Hoshino T, Imahori K (1993) Tau protein 
kinase I is essential for amyloid beta-protein-induced neurotoxicity. Proc Natl Acad Sci U S A 90:7789-7793.

Tompa P, Emori Y, Sorimachi H, Suzuki K, Friedrich P (2001) Domain III of calpain is a Ca2+-regulated phospholipid-binding domain. Biochem Biophys Res Commun 280:1333-1339.

Towbin H, Staehelin T, Gordon J (1979) Electrophoretic transfer of proteins from polyacrylamide gels to nitrocellulose sheets: procedure and some applications. Proc Natl Acad Sci U S A 76:4350-4354.

Tsai LH, Lee MS, Cruz J (2004) Cdk5, a therapeutic target for Alzheimer's disease? Biochim Biophys Acta 1697:137-142.

van der Bliek AM, Redelmeier TE, Damke H, Tisdale EJ, Meyerowitz EM, Schmid SL (1993) Mutations in human dynamin block an intermediate stage in coated vesicle formation. J Cell Biol 122:553-563.

Vassar R, Bennett BD, Babu-Khan S, Kahn S, Mendiaz EA, Denis P, Teplow DB, Ross S, Amarante P, Loeloff R, Luo Y, Fisher S, Fuller J, Edenson S, Lile J, Jarosinski MA, Biere AL, Curran E, Burgess T, Louis JC, et al. (1999) Beta-secretase cleavage of Alzheimer's amyloid pre- cursor protein by the transmembrane aspartic protease BACE. Science 286:735-741.

Vaughan CJ (2003) Prevention of stroke and dementia with statins: effects beyond lipid lowering. Am J Cardiol 91:23B-29B.

Wei Z, Song MS, MacTavish D, Jhamandas JH, Kar S (2008) Role of calpain and caspase in beta-amyloid-induced cell death in rat primary septal cultured neurons. Neuropharmacology 54:721-733.

Wolozin B, Manger J, Bryant R, Cordy J, Green RC, McKee A (2006) Reassessing the relationship between cholesterol, statins and Alzheimer's disease. Acta Neurol Scand Suppl 185:63-70.

Wood JG, Mirra SS, Pollock NJ, Binder LI (1986) Neurofibrillary tangles of Alzheimer disease share antigenic determinants with the axonal microtubule-associated protein tau (tau). Proc Natl Acad Sci U S A 83:4040-4043.

Yakunin AF, Hallenbeck PC (1998) A luminol/iodophenol chemiluminescent detection system for Western immunoblots. Anal Biochem 258:146149 